\title{
Host genetic control of gut microbiome composition
}

\author{
Jason A. Bubier ${ }^{1}\left[\right.$. Elissa J. Chesler ${ }^{1}$. George M. Weinstock ${ }^{2}$ \\ Received: 21 December 2020 / Accepted: 7 April 2021 / Published online: 22 June 2021 \\ (c) The Author(s) 2021
}

\begin{abstract}
The gut microbiome plays a significant role in health and disease, and there is mounting evidence indicating that the microbial composition is regulated in part by host genetics. Heritability estimates for microbial abundance in mice and humans range from (0.05-0.45), indicating that 5-45\% of inter-individual variation can be explained by genetics. Through twin studies, genetic association studies, systems genetics, and genome-wide association studies (GWAS), hundreds of specific host genetic loci have been shown to associate with the abundance of discrete gut microbes. Using genetically engineered knockout mice, at least 30 specific genes have now been validated as having specific effects on the microbiome. The relationships among of host genetics, microbiome composition, and abundance, and disease is now beginning to be unraveled through experiments designed to test causality. The genetic control of disease and its relationship to the microbiome can manifest in multiple ways. First, a genetic variant may directly cause the disease phenotype, resulting in an altered microbiome as a consequence of the disease phenotype. Second, a genetic variant may alter gene expression in the host, which in turn alters the microbiome, producing the disease phenotype. Finally, the genetic variant may alter the microbiome directly, which can result in the disease phenotype. In order to understand the processes that underlie the onset and progression of certain diseases, future research must take into account the relationship among host genetics, microbiome, and disease phenotype, and the resources needed to study these relationships.
\end{abstract}

\section{Host genetic control of the microbiome impacts health and disease}

Candidate genes and genome-wide association studies (GWAS) have yielded significant insight into the genetic variations influencing health and disease. Due in large part to advances in next generation, high-throughput sequencing, and proteomics platforms, the number of reports on the contribution of the gut microbiome to certain diseases has escalated in recent years. The human gut contains $10^{13}-10^{14}$ bacteria from thousands of species, and their collective genomes contain $>150$ times more genes than the human or mouse genome (Backhed et al. 2005; Gill et al. 2006; Sender et al. 2016). These bacteria (and viruses, fungi, etc.) are collectively termed the gut microbiome, and their gene content (the metagenome) is often called our second genome (Grice

Jason A. Bubier

Jason.Bubier@jax.org

1 The Jackson Laboratory for Mammalian Genetics, 600 Main Street, Bar Harbor, ME 04609, USA

2 The Jackson Laboratory for Genomic Medicine, Farmington, CT 06032, USA and Segre 2012). Like the host genome, the gut microbiome composition and diversity in each individual are unique (Huse et al. 2012; Zhou et al. 2013).

There is growing awareness in the medical community that an imbalance of the gut microbiome (dysbiosis) is associated with various local and systemic diseases (Shreiner et al. 2015). Dysbiosis has become a hallmark of many diseases, often seen as a symptom of the disease, but not generally considered in the pathogenesis of the disease (Wilkins et al. 2019). Studies using fecal microbiome transplantation (FMT) between obese and lean mice (Turnbaugh et al. 2008) and between lean and obese human donors into mice (Ridaura et al. 2013) indicated that the donor phenotype was transferred to the recipient by the microbiome, demonstrating that the remarkable role commensals play in modulating host phenotype. Since the largest pool of microbes exists in the distal gastrointestinal tract, dysbiosis of the gut microbiome is most readily associated with region-specific gastrointestinal diseases such as Crohn's disease, inflammatory bowel disease (IBD), irritable bowel syndrome (IBS), colorectal cancer, and celiac disease (reviewed in (Gorkiewicz and Moschen 2018)). More recently, attention has turned to the role of 
the gut microbiome in behavioral and neurological conditions. FMT from a healthy donor to an afflicted patient has been reported to mitigate disease severity in individuals with autism spectrum disorder (Yang et al. 2020) and multiple sclerosis (Engen et al. 2020; Schepici et al. 2019). Other neurological conditions such as Parkinson's disease (Sampson et al. 2016) and depression (Zheng et al. 2016) have also shown a microbiome-dependent component. Together, these studies demonstrate that the gut microbiome can influence the pathogenesis of not only gastrointestinal diseases, but also behavioral and neurological conditions, likely involving microbial metabolites that function along the gut-brain axis (Cryan et al. 2019).

FMT has become the standard of care for recurrent Clostridium difficile infections (Brandt 2012; Wilcox et al. 2020). The clinical benefits of such treatment are only realized if there is successful colonization of donor microbiota in the new host. Some FMT treatments only result in a transient repopulation and may need to be repeated. This transient colonization may be due to host genetic factors preventing successful engraftment. Understanding the host genetic factors that influence microbial engraftment is, thus, essential to establish more practical and cost-effective transplant therapies. Furthermore, the development of therapies that are not dependent on the microbe itself but rather the small-molecule metabolites made by the microbe would be applicable to all hosts.

\section{Host genetics associated with microbiome composition in humans}

Analysis of sequencing data of the human genome completed in 2003 (International Human Genome Sequencing 2004) and the human microbiome in 2016 revealed an association of various diseases with both our human genome and our gut commensals (Human Microbiome Project 2012). These efforts, combined with international programs such as the Metagenomics of the Human Intestinal Tract project (Lee-Sarwar et al. 2020), have provided insight into the crucial host-microbe interactions that function in health and disease. These projects have also contributed numerous bioinformatics tools and reference databases, enhancing our understanding of the specific function of the microbiome in the pathoetiology of disease.

As outlined in Fig. 1, much has been learned from the human genome as to how a host genetic variant may result in an altered phenotype. The variant may directly (Pathway I) or indirectly (through alterations in the expression of downstream genes for example, Pathway II) modulate a phenotype. The altered phenotype from these two pathways could

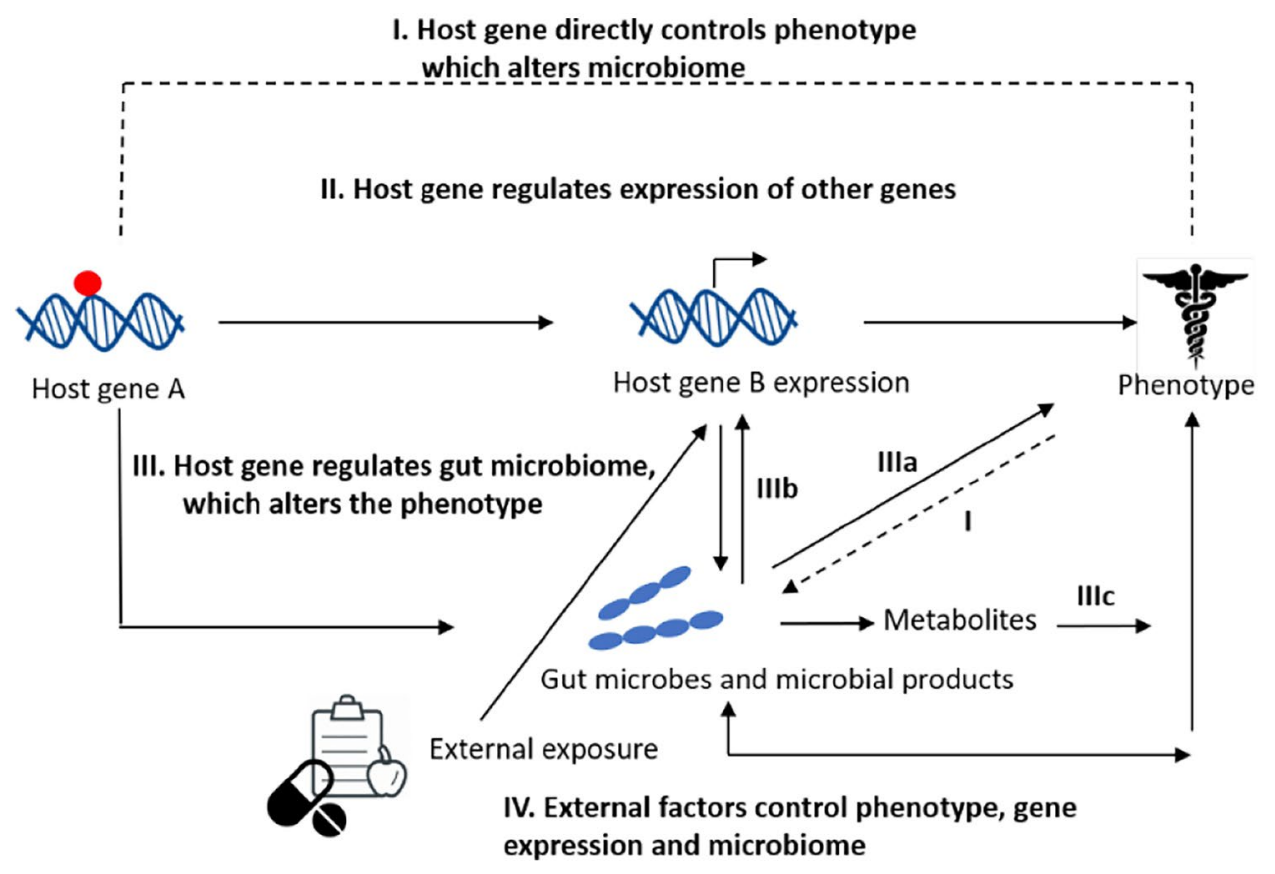

Fig. 1 Model representing possible direct and indirect pathways by which the gut microbiome and host genetics control phenotype. I. Individuals with certain gene variants (indicated by red dot) are susceptible to development of an altered phenotype. II. The gene variant modulates the expression of downstream genes and subsequently affects a phenotype, which can alter the microbiome. III. Host genes determine the gut microbiome composition directly. The gut microbiome (IIIa) and their products (such as short-chain fatty acids) can directly modulate the phenotype (IIIc), and/or indirectly affect the phenotype by affecting host gene expression (IIIb). External factors (IV) such as diet or drugs can alter the gut microbiome, leading to a microbiome driven 
in turn circle back and modulate the microbiome. Finally, a host genetic variant may directly impact the gut microbiome (Pathway III) which in turn may result in an altered host phenotype either directly through their cell surface molecules (Pathway IIIa), metabolites such as short-chain fatty acids (Pathway IIIc) or indirectly through subsequent effects on host genes (Pathway IIIb).

FMT is the preferred approach for defining cause and effect, but has inherent limitations. Transplantation of numerous recipient mice with the samples from a single human with a specific disease (and a single human control) are underpowered as they represent an $n=1$ approach (Walter et al. 2020). Further, many studies pool donor samples resulting in an inability to determine what microbiome composition was responsible for the phenotype. Finally, multiple studies fail to verify engraftment, so it is uncertain if failure to alter a phenotype is the true outcome or due to engraftment failure. Future experiments are encouraged to increase rigor to address causality by not pooling donor samples, verifying engraftment of the differential microbiomes (determining if the animals are dysbiotic) and taking other conservative measures to avoid the overstatement of a study's conclusions (Walter et al. 2020).

The role for the microbiome in host phenotypes is very relevant for discovering genotype-phenotype relations such as in GWAS or other human genetic approaches. The vast majority of this work does not include microbiome analysis and, thus, assumes the mechanisms of Pathways I or II in Fig. 1. A phenotype mediated through the microbiome (Pathway III) presents a different mechanism and, thus, has different approaches to diagnosis and therapy when it is disease related. Moreover, since there is variability in the microbiome between subjects, this can manifest as phenotypic variation, lower penetrance, or other effects that influence human genetic analysis and its use in the clinic. Deeper understanding of microbiome-host genetic relationships is, thus, crucial for medical applications.

A subset of diseases exists for which the genetics of the host determine the microbiome. The most well-studied example is the disorder familial Mediterranean fever (FMF), a genetic autoinflammatory disorder that causes recurrent fevers and painful inflammation in the abdomen, lungs, and joints. FMF is linked to a mutation in the human $M E F V$ (Mediterranean fever) gene, which encodes the pyrin protein, a regulator of the innate immune system (Di Ciaula et al. 2020). $M E F V$, through its innate immune function, also controls the gut microbiome composition (Di Ciaula et al. 2020). During times of active FMF, the gut microbiome exhibits a depletion of total numbers of bacteria, loss of diversity, and shifts in relative abundance of populations of Bacteroidetes, Firmicutes, and Proteobacteria phyla (Khachatryan et al. 2008). As the change in microbiome composition occurs during time of active disease symptoms, the pathway of control would be a direct route where the genetic variant impacts the phenotype (i.e., causes MEFV), which results in a subsequent altered microbiome.

\section{Microbiome composition is a complex heritable trait}

Heritability is defined as the fraction of phenotypic variation that can be attributed to a genetic origin. Twin cohort microbiome studies utilizing monozygotic and dizygotic twin cohorts indicate that host genetics control the makeup of the gut microbiome, and that colonization by discrete taxa is highly heritable (Goodrich et al. 2016, 2014; Lim et al. 2017; Turnbaugh et al. 2009; Xie et al. 2016). In a 2014 study of 416 twin pairs, Goodrich et al. (Goodrich et al. 2014) showed using the classic 16S rRNA gene-sequencing approach, in which a region of the 16S rRNA is amplified, sequenced, and compared to databases for taxonomic assignment that $5.3 \%$ of the taxa had a heritability greater than 20\% (Xie et al. 2016). In 2017, Lim et al. (Lim et al. 2017) showed using the same approach that among 85 taxa, more than half were significantly heritable with heritability ranging between 13.1 and $45.7 \%$, depending on the microbe. A single twin study utilizing a whole-genome shotgunsequencing approach (Xie et al. 2016) showed strong heritabilities for Dorea (42.2\%) and Bifidobacterium (30.9\%) abundance. These significant heritability estimates demonstrate that microbial abundance is amenable to genetic mapping as a complex trait.

\section{Twin studies identify genomic loci associated with microbial abundance in humans}

The twin studies described above were powered well enough to not only calculate heritability for microbial abundance but also identify genomic regions associated with the abundance of specific microbes (Table 1). The most significant findings from the Goodrich studies (Goodrich et al. 2016, 2014) were the association of a SNP (rs2164210) in the lactase gene $(L C T)$ with the abundance of Bifidobacterium $(p<0.001)$ and a SNP (rs2276731) in the gene for an aldehyde dehydrogenase family member $(A L D H 1 L 1)$ with the abundance of unclassified SHA-98 bacteria $(p<0.001)$. In another twin study, a SNP (rs651821) in the apolipoprotein A5 (APOA5) gene was associated with the abundance of Bifidobacterium in patients with metabolic syndrome (Lim et al. 2017). Twin studies used to calculate the heritability of a trait are most useful for microbiome traits as vertical transmission (mother to offspring) is controlled for in these studies. These twin studies show that specific genomic loci that function in regulating the abundance of discrete gut microbes can be identified by utilizing cohorts of monozygotic vs dizygotic twins to disentangle the shared genetic and environmental factors. 
Table 1 Human loci associated with microbial abundance

\begin{tabular}{|c|c|c|c|c|c|c|c|}
\hline Approach & Chromosome & SNP & Gene & Microbe & Target & $\begin{array}{l}\text { Sample } \\
\text { size }\end{array}$ & Reference \\
\hline Twin Studies & 11 & rs651821 & APOA5 & Bifidobacterium & $16 \mathrm{~S} \mathrm{~V} 4$ & 655 & (Lim et al. 2017) \\
\hline \multirow[t]{8}{*}{ Twin Studies } & 3 & rs 2276731 & $A L D H 1 L 1$ & Unclassified SHA-98 & $16 \mathrm{~S} \mathrm{V4}$ & 1126 & (Xie et al. 2016) \\
\hline & 2 & rs6730157 & $R A B 3 G A P 1$ & Bifidobacterium & & & \\
\hline & 2 & rs2164210 & $L C T$ & Bifidobacteria & & & \\
\hline & 7 & rs 1360741 & $C D 36$ & Blautia & & & \\
\hline & 11 & rs 1506977 & OR6A2 & $\begin{array}{l}\text { Cc } 115 \text { (family } \\
\text { Erysipelotrichaceae) }\end{array}$ & & & \\
\hline & 7 & rs1182182 & GNA12 & $\begin{array}{l}\text { SMB53 (family } \\
\text { Clostridiaceae) }\end{array}$ & & & \\
\hline & 11 & rs 1506977 & rs 1506977 & $\begin{array}{l}\text { Cc } 115 \text { (family } \\
\text { Erysipelotrichaceae) }\end{array}$ & & & \\
\hline & 7 & rs1182182 & GNA12 & $\begin{array}{l}\text { SMB53 (family } \\
\text { Clostridiaceae)SS }\end{array}$ & & & \\
\hline \multirow[t]{2}{*}{$\begin{array}{l}\text { Genetic associa- } \\
\text { tion }\end{array}$} & 16 & $\begin{array}{l}\text { rs2066847, } \\
\text { rs2066844, } \\
\text { rs2066845, }\end{array}$ & NOD2 & $\begin{array}{l}\text { depletion of Bacteroi- } \\
\text { detes and Fir- } \\
\text { micutes (particularly } \\
\text { Clostridium taxa) }\end{array}$ & 16S V1-V9 & 178 & (Frank et al. 2011) \\
\hline & 2 & rs2241880 & $A T G 16 L 1$ & $\begin{array}{l}\text { depletion of Bacteroi- } \\
\text { detes and Fir- } \\
\text { micutes (particularly } \\
\text { Clostridium taxa) }\end{array}$ & 16S V1-V9 & & \\
\hline $\begin{array}{l}\text { Genetic associa- } \\
\text { tion }\end{array}$ & 19 & rs601338 & $F U T 2$ & $\begin{array}{l}\text { Alistipes, unclassified } \\
\text { Lachnospiraceae, } \\
\text { and Coprococcus }\end{array}$ & $16 \mathrm{~S} V 1-2$ & 47 & $\begin{array}{l}\text { (Rausch et al. } \\
\text { 2011) }\end{array}$ \\
\hline $\begin{array}{l}\text { Genetic associa- } \\
\text { tion }\end{array}$ & 19 & rs601338 & $F U T 2$ & Bifidobacteria & 16S V6-V8 & 71 & $\begin{array}{l}\text { (Wacklin et al. } \\
\text { 2011) }\end{array}$ \\
\hline $\begin{array}{l}\text { Genetic Associa- } \\
\text { tion }\end{array}$ & 6 & & $H L A-D R B 1$ & Prevotella copri & 16S V1-V2 & 114 & (Scher et al. 2013) \\
\hline $\begin{array}{l}\text { Genetic Associa- } \\
\text { tion }\end{array}$ & 16 & $\begin{array}{l}\text { rs2066844, } \\
\text { rs2066845, } \\
\text { rs5743277, } \\
\text { rs5743293, } \\
\text { rs } 104895431, \\
\text { rs104895467 }\end{array}$ & NOD2 & Enterobacteriaceae & $16 \mathrm{~S} \mathrm{V4}$ & 474 & $\begin{array}{l}\text { (Knights et al. } \\
\text { 2014) }\end{array}$ \\
\hline GWAS & 3 & rs4894707 & $P L D 1$ & Akkermansia & $16 \mathrm{~S} \mathrm{V4}$ & 114 & $\begin{array}{l}\text { (Davenport et al. } \\
\text { 2015) }\end{array}$ \\
\hline \multirow[t]{7}{*}{ GWAS } & 2 & rs56064699 & $L C T$ & Bifidobacterium & $16 \mathrm{~S} V 3-5$ & 93 & $\begin{array}{l}\text { (Blekhman et al. } \\
\text { 2015) }\end{array}$ \\
\hline & 2 & rs1050115 & $U B X N 4$ & Bifidobacterium & & & \\
\hline & 3 & rs1110168 & $P L X N D 1$ & Prevotella & & & \\
\hline & 11 & rs1966834 & OR1S1 & Prevotella & & & \\
\hline & 14 & rs8019270 & $T B P L 2$ & Prevotella & & & \\
\hline & 20 & rs2274669 & PCEDIA & Alistipes & & & \\
\hline & 7 & rs10248138 & EPDR 1 & Lachnobacterium & & & \\
\hline \multirow[t]{6}{*}{ GWAS } & 1 & rs12137699 & VANGL1 & Family Sutterellaceae & WGS & 1514 & $\begin{array}{l}\text { (Bonder et al. } \\
\text { 2016) }\end{array}$ \\
\hline & 2 & rs7605872 & & $\begin{array}{l}\text { Species Dialister } \\
\quad \text { invisus }\end{array}$ & & & \\
\hline & 6 & rs4548017 & & Class Methanobacteria & & & \\
\hline & 9 & rs 1081306616 & LINGO2 & Genus Blautia & & & \\
\hline & 10 & rs1889714 & & $\begin{array}{l}\text { Species Dialister } \\
\text { invisus }\end{array}$ & & & \\
\hline & 11 & rs16913594 & & $\begin{array}{l}\text { Species Bacteroides } \\
\quad \text { xylanisolvens }\end{array}$ & & & \\
\hline
\end{tabular}


Table 1 (continued)

\begin{tabular}{|c|c|c|c|c|c|c|c|}
\hline Approach & Chromosome & SNP & Gene & Microbe & Target & $\begin{array}{l}\text { Sample } \\
\text { size }\end{array}$ & Reference \\
\hline & 11 & rs17115310 & & $\begin{array}{l}\text { Family } \\
\text { Acidaminococcaceae }\end{array}$ & & & \\
\hline & 12 & rs 10743315 & & $\begin{array}{l}\text { Species Lachno- } \\
\text { spiraceae bacterium } \\
11 \text { 57FAA }\end{array}$ & & & \\
\hline & 21 & rs2834288 & & $\begin{array}{l}\text { Family } \\
\text { Oscillospiraceae }\end{array}$ & & & \\
\hline \multirow[t]{7}{*}{$\begin{array}{l}\text { GWAS } \\
\text { (replicated) }\end{array}$} & 2 & rs62171178 & $U B R 3$ & Rikenellaceae & & & $\begin{array}{l}\text { (Turpin et al. } \\
\text { 2016) }\end{array}$ \\
\hline & 3 & rs1394174 & CNTN6 & Faecalibacterium & & & \\
\hline & 1 & rs59846192 & $D M R T B 1$ & Lachnospira & & & \\
\hline & 18 & rs28473221 & $S A L L 3$ & Eubacterium & & & \\
\hline & 4 & rs3775467 & MMRN1 & Weissella & & & \\
\hline & 12 & $\begin{array}{l}\text { chr12:136,228 } \\
39: D\end{array}$ & $\begin{array}{l}\text { LINC01559 } \\
\text { RNA5SP353 } \\
\text { GRIN2B }\end{array}$ & Weissella & & & \\
\hline & 1 & rs6666120 & ACTL8 & Methanobrevibacter & & & \\
\hline \multirow[t]{3}{*}{$\begin{array}{l}\text { GWAS (followed } \\
\text { TWIN) }\end{array}$} & 3 & rs7433197 & FHIT & $\begin{array}{l}\text { Clostridiales (OTU } \\
181,702)\end{array}$ & $16 \mathrm{~S} \mathrm{~V} 4$ & 3666 & $\begin{array}{l}\text { (Beaumont et al } \\
\text { 2016; Le Roy } \\
\text { et al. 2018) }\end{array}$ \\
\hline & 6 & rs1433723 & $T D R G 1$ & $\begin{array}{l}\text { Clostridiales (OTU } \\
25,576)\end{array}$ & & & \\
\hline & 1 & rs2480677 & ELAVL4 & Blautia (OTU 194,733) & & & \\
\hline \multirow[t]{15}{*}{ GWAS } & 1 & rs938295 & FBLIM1 & $\begin{array}{l}\text { Unclassified } \\
\text { Enterobacteriaceae }\end{array}$ & 16S V1-V2 & 1812 & (Wang et al. 2016) \\
\hline & 1 & rs75036654 & LINC01137 & $\begin{array}{l}\text { Unclassified } \\
\text { Acidaminococcaceae }\end{array}$ & & & \\
\hline & 1 & rs597205 & C1orf183 & $\begin{array}{l}\text { OTU13305 } \\
\text { Fecalibacterium } \\
\text { Species-level OTU }\end{array}$ & & & \\
\hline & 2 & rs4669413 & $\begin{array}{l}R P 11- \\
521 D 12.1\end{array}$ & Blautia genus & & & \\
\hline & 2 & rs79387448 & SLC9A2 & Blautia genus & & & \\
\hline & 2 & rs 10928827 & HS6ST1 & $\begin{array}{l}\text { Bacilli } \\
\text { class/Lactobacillales } \\
\text { order }\end{array}$ & & & \\
\hline & 2 & rs4621152 & $\begin{array}{l}A C 007557 \\
1\end{array}$ & $\begin{array}{l}\text { Gammaproteobacteria } \\
\text { class }\end{array}$ & & & \\
\hline & 2 & rs56006724 & C2orf83 & $\begin{array}{l}\text { Unclassified } \\
\text { Acidaminococcaceae }\end{array}$ & & & \\
\hline & 3 & rs11915634 & CNTN6 & $\begin{array}{l}\text { Marinilabiliaceae } \\
\text { family/Unclassified } \\
\text { Marinilabiliaceae }\end{array}$ & & & \\
\hline & 3 & rs3925158 & $S L C 22 A 13$ & $\begin{array}{l}\text { OTU10032 unclas- } \\
\text { sified Enterobacte- } \\
\text { riaceae Species-level } \\
\text { OTU }\end{array}$ & & & \\
\hline & 3 & rs13096731 & $F L N B$ & Escherichia Shigella & & & \\
\hline & 3 & rs59042687 & LINC00879 & Lactobacillales order & & & \\
\hline & 3 & rs9831278 & LINC00973 & $\begin{array}{l}\text { Unclassified } \\
\text { Marinilabiliaceae }\end{array}$ & & & \\
\hline & 3 & rs62295801 & LINC01192 & Lactobacillales order & & & \\
\hline & 3 & rs7646786 & LOC344887 & Bacilli class & & & \\
\hline
\end{tabular}


Table 1 (continued)

\begin{tabular}{|c|c|c|c|c|c|c|c|}
\hline Approach & Chromosome & SNP & Gene & Microbe & Target & $\begin{array}{l}\text { Sample } \\
\text { size }\end{array}$ & Reference \\
\hline & 4 & rs7656342 & DRD5 & $\begin{array}{l}\text { Unclassified } \\
\text { Porphyromonadaceae }\end{array}$ & & & \\
\hline & 4 & rs11724031 & SHROOM 3 & $\begin{array}{l}\text { Marinilabiliaceae } \\
\text { family }\end{array}$ & & & \\
\hline & 4 & rs 17421787 & $\begin{array}{l}\text { RP11- } \\
422 J 15.1\end{array}$ & $\begin{array}{l}\text { Erysipelotrichaceae } \\
\text { family }\end{array}$ & & & \\
\hline & 5 & rs9291879 & $C D 180$ & $\begin{array}{l}\text { Unclassified } \\
\text { Porphyromonadaceae }\end{array}$ & & & \\
\hline & 5 & rs 249733 & SPRY4 & $\begin{array}{l}\text { OTU10032 unclas- } \\
\text { sified } \\
\text { Enterobacteriaceae }\end{array}$ & & & \\
\hline & 7 & rs17661843 & $A B C A 13$ & $\begin{array}{l}\text { Unclassified } \\
\text { Acidaminococcaceae }\end{array}$ & & & \\
\hline & 8 & rs 13276516 & $T G S 1$ & $\begin{array}{l}\text { OTU10032 unclas- } \\
\text { sified } \\
\text { Enterobacteriaceae }\end{array}$ & & & \\
\hline & 8 & rs 2318350 & COL22A1 & $\begin{array}{l}\text { OTU10032 unclas- } \\
\text { sified Enterobacte- } \\
\text { riaceae Species-level } \\
\text { OTU }\end{array}$ & & & \\
\hline & 9 & rs17085775 & C9orf71 & $\begin{array}{l}\text { OTU10032 unclas- } \\
\text { sified } \\
\text { Enterobacteriaceae }\end{array}$ & & & \\
\hline & 10 & rs7083345 & $\begin{array}{l}\text { RP11- } \\
55418.2\end{array}$ & $\begin{array}{l}\text { Lactobacillales } \\
\text { order/Bacilli class }\end{array}$ & & & \\
\hline & 11 & rs7113056 & $\begin{array}{l}R P 11- \\
166 D 19.1\end{array}$ & Lactobacillales order & & & \\
\hline & 12 & rs479105 & PRMT8 & Bacilli class & & & \\
\hline & 12 & rs1009634 & $A K A P 3$ & $\begin{array}{l}\text { OTU10032 unclas- } \\
\text { sified Enterobacte- } \\
\text { riaceae Species-level } \\
\text { OTU }\end{array}$ & & & \\
\hline & 13 & rs9300430 & $R A P 2 A$ & $\begin{array}{l}\text { Gammaproteobacteria } \\
\text { class }\end{array}$ & & & \\
\hline & 14 & rs9323326 & SLC35F4 & Proteobacteria phylum & & & \\
\hline & 14 & rs986417 & SIX6 & $\begin{array}{l}\text { Unclassified } \\
\text { Acidaminococcaceae }\end{array}$ & & & \\
\hline & 14 & rs11626933 & C14orf102 & $\begin{array}{l}\text { Unclassified } \\
\text { Erysipelotrichaceae }\end{array}$ & & & \\
\hline & 15 & rs12442649 & $T M C O 5 A$ & $\begin{array}{l}\text { OTU15355 Dialister } \\
\text { Species-level OTU }\end{array}$ & & & \\
\hline & 15 & rs35275482 & $B N I P 2$ & $\begin{array}{l}\text { Enterobacteriaceae } \\
\text { family }\end{array}$ & & & \\
\hline & 16 & rs12149695 & FLJ21408 & $\begin{array}{l}\text { OTU10032 unclas- } \\
\text { sified } \\
\text { Enterobacteriaceae }\end{array}$ & & & \\
\hline & 16 & rs1362404 & TOX3 & Lactobacillales order & & & \\
\hline & 18 & rs11877825 & $N A P G$ & $\begin{array}{l}\text { Erysipelotrichaceae } \\
\text { family }\end{array}$ & & & \\
\hline & 19 & rs148330122 & SIPA1L3 & Bacilli class & & & \\
\hline & 20 & rs2071199 & $H N F 4 A-A S 1$ & Bacilli class & & & \\
\hline & 21 & rs34613612 & KRTAP8-1 & Actinobacteria class & & & \\
\hline GWAS & 9 & rs150018970 & RAPGEF1 & Ruminococcus & $16 \mathrm{~S} \mathrm{~V} 4$ & 3890 & $\begin{array}{l}\text { (Hughes et al. } \\
\text { 2020) }\end{array}$ \\
\hline
\end{tabular}


Table 1 (continued)

\begin{tabular}{|c|c|c|c|c|c|c|c|}
\hline Approach & Chromosome & SNP & Gene & Microbe & Target & $\begin{array}{l}\text { Sample } \\
\text { size }\end{array}$ & Reference \\
\hline & 1 & rs561177583 & & Coprococcus & & & \\
\hline & 16 & rs55808472 & ARHGAP17 & Butyricicoccus & & & \\
\hline & 11 & rs4494297 & EXT2 & Sutterellaceae & & & \\
\hline & 11 & rs7118902 & SOR11 & Dialister & & & \\
\hline & 13 & rs 35980751 & $\mathrm{ABCC} 4$ & Porphyromonadaceae & & & \\
\hline & 6 & rs 13207588 & FOXP4 & Parabacteroides & & & \\
\hline & 2 & rs6733298 & CCDC85A & Erysipelotrichaceae & & & \\
\hline & 15 & rs116865000 & & Gammaproteobacteria & & & \\
\hline & 9 & rs11788336 & IKBKAP & Firmicutes & & & \\
\hline & 6 & rs 34656657 & ATXN1 & Firmicutes & & & \\
\hline & 4 & rs116135844 & SPOK3 & Bacteroidales & & & \\
\hline & 15 & rs117338748 & LIPC & Veillonella & & & \\
\hline \multirow[t]{5}{*}{ GWAS } & 16 & rs3803713 & HS3ST4 & Faecalibacterium & $16 \mathrm{~S} \mathrm{V3-V4}$ & 1,068 & $\begin{array}{l}\text { (Ishida et al. } \\
\text { 2020) }\end{array}$ \\
\hline & 21 & rs2839417 & $\mathrm{C} 2 \mathrm{CD} 2$ & Erysipelotrichaceae & & & \\
\hline & 2 & rs6545786 & $2 \mathrm{p} 16.1$ & Prevotella & & & \\
\hline & 10 & rs1033781 & $10 \mathrm{p} 15.1$ & Oscillospira & & & \\
\hline & 18 & rs885034 & $18 \mathrm{q} 12.2$ & Alpha diversity index & & & \\
\hline \multirow[t]{20}{*}{ GWAS } & & rs 182549 & LCT & Bifidobacterium & 16S Various & 18,340 & $\begin{array}{l}\text { (Kurilshikov et al. } \\
\text { 2021) }\end{array}$ \\
\hline & 3 & rs9864379 & & Gastranaerophilales & $\begin{array}{l}\mathrm{V} 4, \mathrm{~V} 3-\mathrm{V} 4 \\
\mathrm{~V} 1-\mathrm{V} 2\end{array}$ & & \\
\hline & 3 & rs 75754569 & IRF1 & Peptococcus & & & \\
\hline & 3 & rs4428215 & FNDC3B & Oxalobacteraceae & & & \\
\hline & 4 & rs 10805326 & & Intestinibacter & & & \\
\hline & 4 & rs11098863 & & Enterorhabdus & & & \\
\hline & 7 & rs 10805326 & & $\begin{array}{l}\text { Eubacterium copros- } \\
\text { tanoligenes }\end{array}$ & & & \\
\hline & 9 & rs602075 & $\begin{array}{l}\text { PCK5,RFK, } \\
\text { GCNT1 }\end{array}$ & Allisonella & & & \\
\hline & 9 & rs736744 & & Oxalobacter & & & \\
\hline & 10 & rs 12781711 & & $\begin{array}{l}\text { Ruminococcaceae } \\
\text { UCG013 }\end{array}$ & & & \\
\hline & 10 & rs61841503 & CUBN & Peptostreptococcacea e & & & \\
\hline & 11 & rs 10769159 & & Ruminococcus1 & & & \\
\hline & 12 & rs 12320842 & & Faecalibacterium & & & \\
\hline & 12 & rs11110281 & & Streptococcus & & & \\
\hline & 13 & rs7322849 & & Bifidobacterium & & & \\
\hline & 14 & rs8009993 & & $\begin{array}{l}\text { Ruminococcaceae } \\
\text { UCG009 }\end{array}$ & & & \\
\hline & 17 & rs7221249 & & Erysipelatoclostridium & & & \\
\hline & 19 & rs67476743 & & Tyzzerella3 & & & \\
\hline & 19 & rs830151 & & $\begin{array}{l}\text { Candidatus } \\
\text { Soleaferrea }\end{array}$ & & & \\
\hline & 19 & rs 35866622 & FUT2-FUT1 & Ruminococcus torques & & & \\
\hline
\end{tabular}




\section{Human genetic association studies or candidate gene studies have associated human genomic regions with microbial abundance}

Another approach to determining genomic linkage is through genetic association studies, which test for correlations between altered phenotype and regional genetic variation to identify genomic loci that contribute to the altered phenotype. Genetic association studies have identified several specific relationships between host genetics and microbiome composition (Table 1). The human major histocompatibility complex, specifically the DRB1 haplotype, a rheumatoid arthritis risk locus, is correlated with Prevotella copri expansion $(p<0.001)$ (Scher et al. 2013) in untreated new-onset rheumatoid arthritis, but once treated, Prevotella copri abundance in chronic patients is not different from healthy controls. The fucosyltransferase 2 (FUT2) gene (Rausch et al. 2011; Wacklin et al. 2011), nucleotide-binding oligomerization domain containing 2 (NOD2) gene, and autophagy-related 16 like 1 (ATG16L1) (Frank et al. 2011) were also associated with microbial abundance using genotype association studies.

\section{Human genome-wide association studies have associated numerous loci with microbial abundance}

Genome-wide association studies (GWAS) utilize the approach of genotype association studies but use large sample sizes and unbiased markers throughout the genome to link genotype to phenotype rather than testing the association of a phenotype with only a specific individual gene or genomic region as in genetic association studies. GWAS can link specific SNPs to a phenotype of interest, such as the composition and abundance of specific microbes within the microbiome. They are superior to twin studies as you are not limited to collecting data from just monozygotic and dizygotic twin samples which makes it difficult to reach large sample sizes and the power to detect traits with lower heritabilities. The linked SNP in GWAS may be in a gene or be associated with the nearest gene or genomic feature by convention. As shown in Table 1, GWAS have enabled the detection of numerous SNPs associated with the abundance of specific microbes. Like the twin studies (Xie et al. 2016), GWAS identified $L C T$ in association with Bifidobacterium (Blekhman et al. 2015). One GWAS confirmed the association of SNPs in ubiquitin-protein ligase $\mathrm{E} 3$ component $n$-recognin 3 (UBR3) gene, contactin 6 (CNTN6) gene, DMRT like family B with proline-rich C-terminal 1(DMRTB1) gene, and spalt-like transcription factor 3 (SALL3) gene that was associated with the abundances of Rikenellaceae, Faecalibacterium, Lachnospira, and Eubacterium, respectively (Turpin et al. 2016) in multiple independent cohorts. The most GWAS hits reported to date were found in a study by Wang et al. (Wang et al. 2016) in which 40 different loci were significantly associated with microbial abundance at a variety of levels (class, order, family, or genus) in two cohorts from northern Germany totaling 1812 individuals. Thus far, only one GWAS study used whole-genome shotgun sequencing rather than $16 \mathrm{~S}$ sequencing to inventory the microbiome composition (Bonder et al. 2016). In this study of 1514 individuals, nine genetic loci were associated with specific microbes classified at levels ranging from the family to the species level. A recent GWAS study utilizing numerous populations and microbiome sequencing methods identified 20 loci and reproduced the $L C T$ association with Bifidobacterium (Kurilshikov et al. 2021). Overall, twin studies, genetic association studies, and GWAS have identified at least 110 different loci associated with the abundance of specific gut microbes.

The GWAS and genetic association studies approach to calculating heritability in microbiome-related traits must be interpreted with caution (Tam et al. 2019). In these studies, vertical transmission from mother to offspring is not controlled for, unlike in twin studies, and the mode of child delivery also affects the microbiome (Dominguez-Bello et al. 2010). In addition, large, population-based studies such as these do not account for diet or environment, two of the strongest drivers of microbiome composition (DominguezBello et al. 2010; Rothschild et al. 2018). In GWAS, the population size and significance level needed to correct for genome-wide multiple testing and for traits of low heritability that remain under consideration (Dudbridge and Gusnanto 2008). GWAS studies only explain a proportion of the heritability, with other factors such as epistatic and gene-environment interactions not captured (Manolio et al. 2009). Finally, associations between host gene and bacterial abundance do not often replicate across GWAS studies, likely due to variation in diet, environment, and specific population studied.

\section{Genetic analysis identifies loci associated with microbial abundance in mice}

Microbiome studies in laboratory mice allow for the control of many variables within an experiment that are not controllable in human studies. Laboratory mice are an important model system for microbiome studies due to the ability to produce germ-free (GF) or microbiome-depleted animals and introduce microbiomes by FMT or by manipulating the microbiome by other methods such as treatment with antibiotics or altering the diet. This type of control is essential as the environment, and diet has been shown to have the most substantial effect on the microbiome (Dong and Gupta 2019; 
Rothschild et al. 2018). When mice are provided a defined environment controlling for location, room, diet, and cage effect within a study, host genetics accounts for a large proportion of remaining microbial variation. The genetic effect on the microbiome is illustrated by the intrinsic difference in microbiome between inbred strains of mice (Benson et al. 2010; Campbell et al. 2012; Leamy et al. 2014; McKnite et al. 2012; Org et al. 2015). The combination of variation in the microbiome by strain and the powerful tools of mouse genetics offer a highly effective approach for studying the genetic control of the microbiome.

Quantitative trait loci (QTL) mapping in genetically diverse mice has enabled the identification of genomic regions associated with the microbiome (Table 2, Supplementary Table 1). The first mouse microbial abundance QTL studies, performed in generation four of a C57BL/6 J x ICR advanced-intercross line (AIL) (Benson et al. 2010) using V1-V2 16S sequence from fecal pellets, identified 18 significant or suggestive host QTL, with each QTL accounting for $1.6-9.0 \%$ of the variation in microbe abundance. AILs accumulate additional crossovers with every successive generation, leading to a population with smaller linkage disequilibrium (LD) blocks. The original study was followed up four years later using the $10^{\text {th }}$ generation intercross of these mice. This mapping cross identified 42 QTL. Each of the identified QTL explains an average variance of $4.64 \%$ of a particular microbe's microbial abundance. Additional studies have been performed through the years, all utilizing $16 \mathrm{~S}$ sequencing for microbiome composition in various mouse populations such as the BXD Recombinant Inbred Panel (McKnite et al. 2012; Perez-Munoz et al. 2019), Collaborative Cross (Bubier et al. 2020; Snijders et al. 2016), Hybrid Mouse Diversity Panel (Org et al. 2015; van Opstal and Bordenstein 2015), and Diversity Outbred (DO) mice (Kemis et al. 2019). These studies have contributed an additional 348 loci associated with microbial abundance (Supplementary Table 1). Particularly for mice, there have been few occurrences of the same locus being found in multiple studies. Some of this 'failure to replicate' can be attributed not only to the differential diets, husbandry practices, and health status found across studies and facilities, but also to the fact that the same genetic polymorphisms are not present in the same populations and would, thus, not be expected to replicate. For example, there will be loci detected in the BXD RI population that will not be detected in the DO because of the lack of DBA2-specific polymorphisms in the latter population. Taken together, the discovery of so many loci suggests that there are many genes involved in the control of the microbiome, but the inability to replicate genetic loci across studies indicates the importance of testing the causative loci using genetic knock-out experiments.

\section{Gene knock-out studies validate host genes controlling microbiome abundance}

A common approach to verifying the involvement of a gene in a process is to inactivate the gene of interest through genetic engineering and define the effect on phenotype. As it relates

Table 2 Mouse microbial QTL mapping studies

\begin{tabular}{|c|c|c|c|c|c|c|}
\hline Publication & \# Strains & Population & Number of Loci & Statistical criteria & Source & Target \\
\hline (Benson et al. 2010) & 645 animals & G4 AIL (B6J x ICR) & 18 & $\begin{array}{l}\text { Significant or sug- } \\
\text { gestive }\end{array}$ & Fecal pellets & $16 \mathrm{~S} \mathrm{V1-2}$ \\
\hline $\begin{array}{l}\text { (Hillhouse et al. } \\
\text { 2011) }\end{array}$ & 314 animals & F2 (B6 x AJ) & 10 & Significant & Cecal contents & Helicobacter \\
\hline (McKnite et al. 2012) & $\begin{array}{l}61 \text { animals (30 } \\
\text { Strains) }\end{array}$ & RI (BXD) & 9 & Significant & Fecal pellets & 16S V1-2 \\
\hline (Leamy et al. 2014) & 472 animals & G10 AIL (B6J x ICR) & 42 & $\begin{array}{l}1 \text { significant post } \\
\text { FDR }\end{array}$ & Fecal pellets & $16 \mathrm{~S} V 1-2$ \\
\hline (Org et al. 2015) & 599 (110 Strains) & HDMP & 7 & Significant & Cecal contents & $16 \mathrm{~S} \mathrm{~V} 4$ \\
\hline (Wang et al. 2015) & 334 animals & $\begin{array}{l}\text { F2( WSB/EiJ x } \\
\text { PWH/PhJ) }\end{array}$ & 20 & Significant & Cecal contents & $16 \mathrm{~S} V 1-2$ \\
\hline (Snijders et al. 2016) & $\begin{array}{l}293 \text { animals (30 } \\
\text { Strains) }\end{array}$ & $\mathrm{RI}(\mathrm{CC})$ & 169 & $-\log 10(\mathrm{P}$ value $)>6)$ & Fecal pellets & $16 \mathrm{~S} \mathrm{~V} 4$ \\
\hline (Kemis et al. 2019) & 500 animals & Outbred (DO) & 28 & 4 Significant & Fecal pellets & $16 \mathrm{~S} \mathrm{V4}$ \\
\hline $\begin{array}{l}\text { (Perez-Munoz et al. } \\
\text { 2019) }\end{array}$ & $\begin{array}{l}\sim 128 \text { animals (32 } \\
\text { Strains) }\end{array}$ & RI (BXD) & 27 & Significant & Cecal contents & 16S V5-V6 \\
\hline (Suzuki et al. 2019) & 70 wild animals & Wild Mice & 24 & $-\log 10(p$ value $)>6)$ & $\begin{array}{l}\text { Cecal contents } \\
\text { and fecal } \\
\text { pellets }\end{array}$ & 16S V4 \\
\hline (Bubier et al. 2020) & $\begin{array}{l}201 \text { animals (108 } \\
\text { Strains) }\end{array}$ & RI (pre-CC) & 18 & Significant post FDR & Cecal contents & $16 \mathrm{~S}$ V1-2, V4 \\
\hline
\end{tabular}


Table 3 Mouse knock-out studies demonstrating altered microbiome composition

\begin{tabular}{|c|c|c|c|}
\hline Gene & $\begin{array}{l}\text { Chromo- } \\
\text { some }\end{array}$ & Phenotype & Reference \\
\hline $\operatorname{Tlr} 5$ & 1 & $\begin{array}{l}\text { The gut microbiotica shows enrichment or reduction of } 116 \text { bacterial phylotypes relative } \\
\text { to wild-type controls and transplanting gut microbiota from homozygotes to germ-free } \\
\text { control hosts confers many aspects of the metabolic disease phenotype }\end{array}$ & $\begin{array}{l}\text { (Chassaing et al. 2014); } \\
\text { (Vijay-Kumar et al. } \\
\text { 2010) }\end{array}$ \\
\hline Card9 & 2 & $\begin{array}{l}\text { The LEfSe analysis revealed differences including decreases in Adlercreutzia (genus), } \\
\text { Actinobacteria (phylum), and Lactobacillus reuter in the Card9-/-mouse microbiota. } \\
\text { Mice fail to metabolize tryptophan into metabolites that act as aryl hydrocarbon recep- } \\
\text { tor (AHR) ligands }\end{array}$ & (Lamas et al. 2016) \\
\hline Pglyrp3 & 3 & $\begin{array}{l}\text { Have reduced Lactobacillus/Lactococcus, Enterobacteriaceae, and Eubacterium } \\
\text { rectale/Clostridium coccoides, and Clostridium perfringen groups }\end{array}$ & (Saha et al. 2010) \\
\hline Pglyrp4 & 3 & $\begin{array}{l}\text { Have reduced Lactobacillus/Lactococcus and segmented filamentous bacteria groups } \\
\text { increased Bacteroides group }\end{array}$ & (Saha et al. 2010) \\
\hline$T l r 2$ & 3 & $\begin{array}{l}\text { Display a threefold increase in Firmicutes and a slight increase in Bacteroidetes com- } \\
\text { pared with controls }\end{array}$ & (Caricilli et al. 2011) \\
\hline Lepr & 4 & $\begin{array}{l}\text { Have a significant higher abundance of Firmicutes, Proteobacteria, and Fibrobacteres } \\
\text { phyla in } \mathrm{db} / \mathrm{db} \text { mice compared to lean mice }\end{array}$ & (Geurts et al. 2011) \\
\hline Ptpn11 & 5 & $\begin{array}{l}\text { Have an increase in Enterobacteriaceae and a decrease in Firmicutes were observed in } \\
\text { the colon of these mice }\end{array}$ & (Coulombe et al. 2016) \\
\hline Aicda & 6 & $\begin{array}{l}\text { Mice exhibit an increase in bacteria, especially anaerobic bacteria, in the small intestine } \\
\text { compared with wild-type mice. Some mice exhibit an expansion of unclassified Lach- } \\
\text { nospiraceae of the order Clostridiales while others exhibit increased Bacteroidales or } \\
\text { Lactobacillus compared with wild-type mice }\end{array}$ & (Wei et al. 2011) \\
\hline $\operatorname{Reg} 3 g$ & 6 & $\begin{array}{l}\text { Mice exhibit a higher mucosal bacterial loads (gram-positive Firmicutes phylum [ Lac- } \\
\text { tobacillus, Eubacterium rectale, and segmented filamentous bacteria (SFB) groups]) } \\
\text { compared with wild-type mice; however, luminal bacterial loads are normal }\end{array}$ & (Vaishnava et al. 2011) \\
\hline Lep & 6 & $\begin{array}{l}\text { ob/ob animals have a } 50 \% \text { reduction in the abundance of Bacteroidetes and a propor- } \\
\text { tional increase in Firmicutes }\end{array}$ & (Ley et al. 2005) \\
\hline Nlrp2 & 7 & $\begin{array}{l}\text { Dysbiosis marked by increased obesity-associated Erysipelotrichaceae but reduced } \\
\text { Lachnospiraceae family and the associated enzymes } \mathrm{r}\end{array}$ & (Truax et al. 2018) \\
\hline Nlrp6 & 7 & $\begin{array}{l}\text { Mice and co-housed wild-type mice exhibit expanded bacterial phylotypes compared } \\
\text { with wild-type mice }\end{array}$ & (Elinav et al. 2011) \\
\hline Pglyrp1 & 7 & Have reduced segmented filamentous bacteria & (Saha et al. 2010) \\
\hline Fut2 & 7 & Salmonella typhimurium susceptibility & (Goto et al. 2014) \\
\hline Nod2 & 8 & $\begin{array}{l}\text { Relative abundances of several clostridial genera were associated with disease pheno- } \\
\text { type, NOD2 composite genotype, and/or ATG16L1genotype }\end{array}$ & $\begin{array}{l}\text { (Frank et al. 2011; } \\
\text { Rehman et al. 2011) }\end{array}$ \\
\hline Myd88 & 9 & $\begin{array}{l}\text { Increased abundances of Lactobacillaceae, Rikenellaceae, and Porphyromonadaceae } \\
\text { phylotype }\end{array}$ & (Wen et al. 2008) \\
\hline Apoal & 9 & $\begin{array}{l}12 \% \text { variation of a Partial Least-Square Discriminate Analysis of microbiota structure } \\
\text { accounted for by genotype }\end{array}$ & (Zhang et al. 2010) \\
\hline Mmp7 & 9 & $\begin{array}{l}\text { Increased sensitivity to Salmonella typhimurium. KO mice also have increase Firmicutes } \\
\text { (specifically Clostridia) an decreased Bacteroidete) compared to wild type }\end{array}$ & $\begin{array}{l}\text { (Wilson et al. 1999), } \\
\text { (Salzman et al. 2010) }\end{array}$ \\
\hline $\operatorname{Atg} 5$ & 10 & $\begin{array}{l}\text { Have a dramatically altered composition of the gut microbiota and reduced alpha diver- } \\
\text { sity. "Candidatus Arthromitus" and the Pasteurellaceae family were increased in KO } \\
\text { mice, whereas Akkermansia muciniphila and the Lachnospiraceae family were reduced }\end{array}$ & (Yang et al. 2018) \\
\hline Ikzfl & 11 & $\begin{array}{l}\text { The intestinal flora contains more numbers and more diverse groups of bacteria than in } \\
\text { controls }\end{array}$ & $\begin{array}{l}\text { (Georgopoulos et al } \\
\text { 1994) }\end{array}$ \\
\hline Nlrp3 & 11 & $\begin{array}{l}\text { Mice fed a Western diet show a greater gut microbiota dysbiosis than controls on the same } \\
\text { diet }\end{array}$ & $\begin{array}{l}\text { (Pierantonelli et al } \\
\text { 2017) }\end{array}$ \\
\hline Pik3cg & 12 & $\begin{array}{l}\text { Between WT and KO } 11 \text { taxa were found to increase significantly and five taxa } \\
\text { decreased significantly in KO mice compared to WT mice }\end{array}$ & (Li et al. 2020) \\
\hline Igha & 12 & Mice deficient in IgA harbor an increased abundance of SFB & (Suzuki et al. 2004) \\
\hline Ccl28 & 13 & The abundance of Class Bacilli bacteria is increased in the intestine & (Matsuo et al. 2018) \\
\hline
\end{tabular}


Table 3 (continued)

\begin{tabular}{|c|c|c|c|}
\hline Gene & $\begin{array}{l}\text { Chromo- } \\
\text { some }\end{array}$ & Phenotype & Reference \\
\hline Sugct & 13 & $\begin{array}{l}\text { Mice show differences in the proportion of and type of bacteria species in stool, with } \\
\text { an increase of firmicutes relative to Bacteroidetes (strongest in Blautia genus contain- } \\
\text { ing the families Ruminococcaceae and Lachnospiraceae, then Adlercreutzia genus, } \\
\text { Bilophilia genus, and AF12 genus and a decrease in Bifidobacterium genus); microbi- } \\
\text { ome changes resemble those seen in microbiome disbalance in metabolic diseases like } \\
\text { diabetes }\end{array}$ & $\begin{array}{l}\text { (Niska-Blakie et al. } \\
\text { 2020) }\end{array}$ \\
\hline Olfm4 & 14 & $\begin{array}{l}\text { Following oral challenge, mice exhibit reduced colonization by Helicobacter pylori and } \\
\text { increased infiltration of inflammatory cells in the gastric mucosa compared with wild- } \\
\text { type mice }\end{array}$ & (Liu et al. 2010) \\
\hline$V d r$ & 15 & $\begin{array}{l}\text { Lactobacillus was depleted in the fecal stool, whereas Clostridium and Bacteroides were } \\
\text { enriched. Bacterial taxa along the Sphingobacteria-to-Sphingobacteriaceae lineage } \\
\text { were enriched }\end{array}$ & (Jin et al. 2015) \\
\hline Retnlb & 16 & $\begin{array}{l}\text { Fifteen Bacteriodetes lineages, and } 1 \text { lineage of Proteobacteria, changed in abundance } \\
\text { between genotypes, whereas } 15 \text { Firmicutes lineages changed in abundance }\end{array}$ & (Hildebrandt et al. 2009) \\
\hline Perccl & 17 & Display an altered intestinal and fecal microbiome composition & (Oz-Levi et al. 2019) \\
\hline Pglyrp2 & 17 & $\begin{array}{l}\text { Have reduced Lactobacillus/Lactococcus, segmented filamentous bacteria, Clostridium } \\
\text { perfringens, and Bacteroides groups }\end{array}$ & (Saha et al. 2010) \\
\hline$N p c 1$ & 18 & $\begin{array}{l}\text { The gut microbiota composition shifted and increased microbial richness and diversity } \\
\text { Specifically, Staphylococcus spp. and unclassified Mogibacteriaceae spp. Mice showed } \\
\text { significantly higher levels in relative abundance in the KO mice compared to WT mice, } \\
\text { whereas the abundance of Allobaculum spp. was significantly lower. Relevantly, the } \\
\text { unclassified Mogibacteriaceae spp }\end{array}$ & (Houben et al. 2019) \\
\hline $\begin{array}{l}\text { HLA- } \\
\text { DRB } 1 * 0401\end{array}$ & $\mathrm{Tg}$ & Clostridium-like bacterium abundance altered & (Gomez et al. 2012) \\
\hline DEFA5 & $\mathrm{Tg}$ & Mice have a decreased proportion of bacteria from the Firmicutes, and decreased SFB & (Salzman et al. 2010) \\
\hline
\end{tabular}

to microbial abundance, the knock-out $(\mathrm{KO})$ of specific genes has been shown to produce distinct gut microbiomes or altered bacterial colonization engraftment compared to control mice in which the target gene is not inactivated. At least 30 genomic loci have been identified that, when deleted from the germline, result in altered microbiome composition, often in addition to other phenotypes (Table 3 ). For example, the absence of activation-induced cytidine deaminase (AID) results in the absence of hypermutated $\operatorname{IgA}$. The lack of $\operatorname{Ig} \mathrm{A}$ in these mice makes them susceptible to predominant and persistent expansion of segmented filamentous bacteria (SFB) (Suzuki et al. 2004). In other examples, an intervention may be necessary to reveal an altered microbiome phenotype in $\mathrm{KO}$ mice. The altered microbiome composition of NLR family, pyrin domain containing 3 (Nlrp3) KO mice (Nlrp3 $3^{\text {tmlBhk}}$ ), is not as apparent until the mice are subjected to environmental manipulation, such as feeding the mice a Western lifestyle diet (Pierantonelli et al. 2017), which exposes the microbiome differences between KO and control mice. The numerous mutations with effects on the microbiome demonstrate the variety of genes through which the host maintains the critical homeostatic regulation of the microbiota.

Conditional deletion of toll-like receptor 5 (Tlr5) from intestinal epithelial cells shows low-grade inflammation, metabolic syndrome, and colitis as compared to wild-type littermates (Chassaing et al. 2014). These conditional KO mice show enrichment or reduction of 116 bacterial phylotypes relative to controls. Antibiotic treatment of the conditional $\mathrm{KO}$ mice eliminates the inflammation and associated metabolic syndrome (Chassaing et al. 2014). Transplanting gut microbiota from homozygote conditional $\mathrm{KO}$ mice to germ-free control hosts confers many aspects of the metabolic disease phenotype on those mice (Vijay-Kumar et al. 2010). These studies specifically showcase the importance of intestinal Tlr5 in the maintenance of the gut microbiome.

Another approach using genetically engineered mice to dissect host control of the microbiome has been to produce mice that express human genes from a transgene. To understand the role of antimicrobial peptides in microbiome composition, the human alpha-defensin (DEFA5) gene, a component of enteric mucosal innate immunity, was introduced into FVB mice (Salzman et al. 2010). The transgenic expression of DEFA5 resulted in mice with a decreased proportion of Firmicutes and decreased SFB colonization compared to non-transgenic control FVB mice. This manipulation suggests that alpha-defensins play an essential role in regulating the makeup of the commensal microbiota. The creation of genetically identical mouse strains that differ in the presence of one gene and that display significant differences in microbiome composition supports the concept that the host 
genotype controls the microbiome and may subsequently affect disease phenotypes.

\section{Cross-species conservation of host genes that modulate the microbiome}

Many confounding factors, especially diet and environment which are strong microbiome composition drivers, prevent replication across studies in humans and mice. Despite these challenges, some loci have demonstrated conserved function across species. For example, the genes NOD2 (Frank et al. 2011; Knights et al. 2014; Rehman et al. 2011) and FUT2 (Goto et al. 2014; Rausch et al. 2011) have been associated with microbiome composition in both species. NOD2 was identified in a human GWAS as a host gene associated with the microbiome composition and inflammatory bowel disease. This dysbiosis was recapitulated in KO mice revealing alteration in multiple distinct microbes associated with the disease phenotype. FUT2, the gene responsible for the ABO histo-blood group antigens, was associated in human studies with Crohn's disease and altered microbial community composition. Fut2 knock-out mice result in altered epithelial fucosylation and increased susceptibility to Salmonella typhimurium. These studies implicate conserved functions across species for NOD2 and FUT2 in modulating the gut microbiome.

\section{Microbiome control of host gene expression}

GF mice display an array of physiological and behavioral abnormalities (Clarke et al. 2013; Desbonnet et al. 2014; Diaz Heijtz et al. 2011; Neufeld et al. 2011). Because they lack a normal microbiota, the epithelial barrier function, gut homeostasis, and innate and adaptive immune functions of GF mice develop differently (Hooper and Gordon 2001; Lundin et al. 2008). These developmental differences result in altered hippocampal serotonergic signaling and altered expression of genes known to be involved in synaptic longterm potentiation in the striatum (Clarke et al. 2013; Diaz Heijtz et al. 2011; van Opstal and Bordenstein 2015). As a result of neural differences, these mice are less anxious and display increased locomotor activity than specific pathogenfree (SPF) control mice (Diaz Heijtz et al. 2011). The presence of an intact microbiome is, thus, an essential requirement for normal development.

Specific microbes have been found to regulate host gene expression. For example, in cultured human cells, lipopolysaccharide (LPS) from Escherichia coli and other proteobacteria caused an inflammatory response by activating toll-like receptor 4 (TLR4), leading to a gene expression cascade of innate immune pathways (Rallabhandi et al. 2008),. Microarray analysis in mice showed that $\sim 700$ host intestinal genes were differentially expressed between GF mice and
SPF mice (Cresci et al. 2010; Liu et al. 2016), which are free of specific pathogens determined from routine testing but are not GF and, thus, harbor a microbiome. The latter showed that bacterial recolonization of the intestinal tract of GF mice reversed some of these gene expression changes. In a different experiment, FMT of germ-free $\mathrm{C} 3 \mathrm{H}$ mice, which harbor a mutation in the Tlr4 gene, with C57BL/10 feces resulted in 202 genes differing more than twofold in expression (Brodziak et al. 2013). The behavioral abnormalities of GF mice related to anxiety were corrected when they were given an SPF microbiome (Cresci et al. 2010; Liu et al.). Similarly, in another mouse experiment, the depletion of the gut microbiome through antibiotic treatment caused cognitive impairment, accompanied by changes in the expression of cognition-relevant signaling molecules in specific regions of the brain (Frohlich et al. 2016). These observations support a host-microbiome interaction model where the microbiome alone can independently modulate the expression of host genes and subsequently affect a phenotype.

There is growing evidence that the effects of the microbiome on host gene expression are modulated through the epigenome. The epigenome is the chemical modifications to DNA and histone proteins that regulate the expression of genes and is thought to be regulated in part by the metabolome (Krautkramer et al. 2017). The metabolome is the collection of metabolites produced during metabolism and includes those metabolites produced by the gut microbiome. Thus, the metabolome can be thought of as the functional intermediate between the microbiome and host gene expression (reviewed in (Krautkramer et al. 2021)). Short-chain fatty acids (SCFAs) produced by the microbiome regulate host defenses and the immune system through epigenetic control by inhibiting histone deacetylation. Butyrate, a known histone deacetylation inhibitor (Davie 2003; Wu et al. 2020), produced by commensal microbes such as Clostridia has been shown to induce regulatory $\mathrm{T}$ cell development by enhancing histone H3 acetylation (Furusawa et al. 2013). The gut microbiome induces epigenetics changes of all types, DNA methylation, histone modification and regulation by non-coding RNA to control gene expression of the host.

\section{Opportunities and considerations in the use of animal models to study host genetic-microbiome interactions}

Animal studies allow researchers to have exquisite control over the environment of their animals. Each research location determines what the SPF health status of their vivarium will be. The health status corresponds to which microbes are excluded, through routine testing, from being present within a mouse colony. This variation in SPF status across vivaria has inadvertently enabled researchers to determine 
that the phenotype of some inbred strains of mice vary based upon the presence of specific microbes. One such example is diabetes, a condition that is present in NOD/ShiLtJt mice. In this well-characterized type 1 diabetes (T1D) model, diabetes develops in young (3-5 week-old) mice as autoreactive T-cells destroy the insulin-producing beta cells in the pancreas. Researchers using this model in vivaria that screen for fewer pathogens (lower SPF status) noticed a decreased incidence of T1D in their NOD/ShiLtJt mice (Pozzilli et al. 1993). This was due to the presence of segmented filamentous bacteria class of microbiota in their facility. The segmented filamentous bacteria class of microbiota is known to influence the severity of the autoimmune response by triggering a counter $\mathrm{Th}_{17}$ immune response that decreases the autoreactivity and protects the mice from developing T1D (Ivanov et al. 2009). This same mouse model displayed decreased T1D when given acidified drinking water, which significantly altered the microbiome, specifically levels of Actinobacteria, Proteobacteria, and Firmicutes, similarly decreasing the $\mathrm{Th}_{17}$ mediated autoreactivity (Wolf et al. 2014). Thus, the control researchers have over the environment of animals that has provided various, sometimes unexpected insights.

A recent commentary emphasizes the importance of "Knowing your model and its microbiota" (Perry et al. 2020). The example that best exemplifies this thesis is the finding that the gut microbiome is causative for a phenotypic change of a mutant transformation-related protein 53 (Trp53) to switch from tumor suppressor to oncogene in the context of a genetic model for intestinal cancer (Csnklal ${ }^{\text {tml.1Ybn }}$ ) (Kadosh et al. 2020). This change was due to the presence of a microbiome-derived metabolite, gallic acid, which abolishes the tumor-suppressive nature of the mutation only in a region of the distal gut where the gallic acid-producing microbe is present. This is an example of an interaction between host genotype (mutant Trp53) and microbiome (gallic acid-producing microbe) that creates an altered phenotype (malignancy). Taken together, a comprehensive view that includes both host genetics and microbiome composition is critical to fully understand the relationship between genes and the manifestation of the disease (van Opstal and Bordenstein 2015).

\section{Experiments to dissect the cause-and-effect relationships of the host and microbiome}

A major challenge for understanding host-microbiome interactions is determining causality of an altered phenotype due to a genetic alteration. As illustrated in Fig. 1, variation in the host genome can alter a phenotype in multiple ways. The ability to transfer a specific phenotype from donor to recipients in FMT experiments is one way to distinguish between the altered microbiome being causative of the disease phenotype or the altered microbiome being a subsequent manifestation of the disease processes. One example is the case of the NOD2 gene, which is associated with both IBD and an altered microbiome (Frank et al. 2011; Rehman et al. 2011). Wild-type mice were transplanted with fecal material from the NOD2 knock-out mouse, and the recipient mice developed features of IBD seen in the NOD2 fecal donor mice (Couturier-Maillard et al. 2013). The transfer of disease phenotype by the transfer of the microbiome suggests that the genetic variant alters the microbiome directly, which results in an altered phenotype (Fig. 1, Pathway III). Similarly, we tested causality using the BKS.CgDock $7^{\mathrm{m}}+/+\mathrm{Lepr}^{\mathrm{db}} / \mathrm{J}$ mouse, a model of leptin deficiency, resulting in obesity, type- 2 diabetes, and abnormal sleep patterns in the form of altered sleep-wake regulation (Laposky et al. 2008). This strain possesses various microbes that are absent in their wild-type littermates (Geurts et al. 2011). We found that treatment of these mice with antibiotics resulted in the restoration of sleep behaviors, suggesting that the genetic variant altered the microbiome, which was responsible for the phenotype (Fig. 1, Pathway III). Additional experimentation is needed to identify the microbe or metabolites involved and the mechanisms through which the microbiome controls sleep behavior. These studies highlight how FMT can be used to define cause-and-effect relationships between microbiome composition and host phenotype.

APP/PS1transgenic mice (Tg), a well-established neurodegenerative model of Alzheimer's disease, are associated with microbiome shifts over time (Bauerl et al. 2018). The microbiomes of wild-type versus. Tg mice begin to diverge at six months of age, with the Tg mice having an increase in the genus Sutterella which is concurrent with the time when the animals develop $\beta$-amyloid deposits in the brain. By 24 months of age, the microbiome of the Tg mice is enriched with Erysipelotrichaceae, a known inflammationrelated microbe. In this case, it is not yet clear what the status of causality is (Fig. 1, Pathways I, II, or III). Experimental observations such as these make causal experimentation such as FMT a priori to determine to what extent the $\mathrm{AD}$-associated changes accelerate the $\mathrm{AD}$ pathology, and if so, whether microbiome-mediated interventions might alter AD pathology.

\section{Important next steps and priorities}

The human and mouse microbiomes have been described as qualitatively alike but quantitatively different (Krych et al. 2013) in that they each include a qualitatively similar core of specific phyla but the abundance of specific phyla and species differ. In contrast to the microbiome, the DNA sequence in the protein-coding regions of the mouse and human genomes is $85 \%$ identical (Mouse Genome Sequencing et al. 2002). Because of this genomic 
conservation, the mouse has an extensive history of being used for understanding the genetics of human health and disease (Hedrich 2012); with emerging populations capturing the genetic diversity equivalent to what is seen in the human population (Saul et al. 2019). The mouse microbiome can be studied in these diverse mouse populations in a controlled laboratory environment, enabling the detection of loci involved in microbial abundance. Modern genomic engineering techniques such as CRISPR/Cas9 make the production of genetic knock-out mice and transgenic mice, a routine procedure. Once loci are identified, they can be validated using these mouse genetic engineering techniques to determine causality.

In order to take the next step and perform necessary causal experimentation, additional resources are needed, and technological barriers need to be addressed. A key limitation to understanding the microbiome of mice through $16 \mathrm{~S}$ sequencing is the lack of diversity of sequenced microbiomes in the reference database. Much of the 16S reference database sequence comes from human samples which have a different microbiome composition than mice. The C57BL/6 J and $L e p^{o b}$ microbiomes have been characterized by two groups (Liu et al. 2020; Suez et al. 2014), producing reference WGS or $16 \mathrm{~S}$ data as well as creating a biobank of 126 species, represented by 244 bacterial strains. This effort included 77 new species being identified. Other groups have addressed microbiome diversity by cataloging the microbiome of six different inbred strains of mice from various institutions that were fed a variety of different diets (Xiao et al. 2015), thereby producing additional mouse-centric $16 \mathrm{~S}$ data for the databases. The German Mouse Intestinal Bacterial Collection has sequenced the $16 \mathrm{~S}$ of microbes from wild mice (Lagkouvardos et al. 2016), and made 104 cultural bacterial strains available on their website (www.dsmz.de/ $\mathrm{miBC}$ ). We are currently working with the Diversity Outbred (J:DO) mouse population (Svenson et al. 2012) and routinely find that $30-50 \%$ of our $16 \mathrm{~S}$ sequences are not in databases and/or represent new taxa that have not been phylogenetically placed and, thus, are not classified. $16 \mathrm{~S}$ sequencing has inherent limitations due to copy number variation, as well as not being ideal to detect some microbial groups. As the field is adopting whole-genome sequencing in place of $16 \mathrm{~S}$ analysis, we have undertaken whole-genome shotgun-sequencing on a subset of mouse samples from a DO cohort and have assembled over 500 new genomes (unpublished). Other recent studies have produced larger sets of new genomes from mouse microbiomes (Lagkouvardos et al. 2016; Liu et al. 2020; Suez et al. 2014; Xiao et al. 2015).

Cataloging the existence of microbes is only step one. Having the microbes isolated to perform inoculation studies in vivo is an ideal intervention for causality studies. One challenge to this approach is the fact that numerous microbes are not able to be cultured in the laboratory. For other microbes, the strains available at microbial stock centers (such as the American Type Culture Collection) may not be the same as the commensal that are found in the mouse gut. One way that unculturable microbes can be studied is as part of the microbial ecosystem through fecal microbiome transplantations. Other approaches to address the unculturable bacteria include antibiotic ablations or metabolite identification studies. The identification of the metabolites causing the phenotypes circumvents the need to culture the microbes all together.

The host genetic control of the microbiome is not just limited to the taxonomic level but also at the taxa-independent metabolite level. Some metabolites are made solely by microbes (e.g., butyrate), and others that are made by the host can also be made by microbes (e.g., serotonin). Instead of adding the microbe back, the microbiome can be removed, or the metabolic product of the microbe added back to the mice. A single microbe may not be responsible for a phenotype; rather, it may be caused by a group of microbes, some of which are depleted and others overabundant in causing a specific biological trait. Ultimately the microbiome is easier to manipulate (e.g., antibiotics, probiotics, prebiotics) than genome manipulation, and metabolic supplementation is even easier for the treatment of disease. These developments open the door to new therapeutic and diagnostic approaches.

\section{Conclusions}

The past two decades have produced many clues as to how the gut microbiome composition is affected by host genetics. These have come from the human twins, genetic association studies and GWAS, and numerous mouse QTL and gene knock-out studies; however, our overall understanding of the role of the host in the regulation of microbiome composition is in its infancy. While this review focuses on the genetics of the host, the diet and environment of the host are wellknown sources of variation of microbiome composition. The superb control of the genetics and environment of laboratory animals within an experiment enables scientists to untangle this mystery. Through the successful design and execution of causal experiments using a controlled intervention such as a genetic knock-out, FMT, specific microbial inoculation, germ-free host, or antibiotic ablation, we will more fully understand the mechanisms controlling the diversity and composition of our bacterial symbionts and commensals. As more mechanisms of host-microbial interactions and the causal relations of microbes and their metabolites to disease become better understood, the development of advanced therapeutic approaches informed by the microbiome becomes a reality. 
Supplementary Information The online version contains supplementary material available at https://doi.org/10.1007/s00335-021-09884-2.

Funding GMW and JAB were funded by U01DA043809. EJC is funded by P50DA039841.

\section{Declarations}

Conflicts of interest The authors have no relevant financial or nonfinancial interests to disclose.

Open Access This article is licensed under a Creative Commons Attribution 4.0 International License, which permits use, sharing, adaptation, distribution and reproduction in any medium or format, as long as you give appropriate credit to the original author(s) and the source, provide a link to the Creative Commons licence, and indicate if changes were made. The images or other third party material in this article are included in the article's Creative Commons licence, unless indicated otherwise in a credit line to the material. If material is not included in the article's Creative Commons licence and your intended use is not permitted by statutory regulation or exceeds the permitted use, you will need to obtain permission directly from the copyright holder. To view a copy of this licence, visit http://creativecommons.org/licenses/by/4.0/.

\section{References}

Backhed F, Ley RE, Sonnenburg JL, Peterson DA, Gordon JI (2005) Host-bacterial mutualism in the human intestine. Science 307:1915-1920

Bauerl C, Collado MC, Diaz Cuevas A, Vina J, Perez Martinez G (2018) Shifts in gut microbiota composition in an APP/PSS1 transgenic mouse model of Alzheimer's disease during lifespan. Lett Appl Microbiol 66:464-471

Beaumont M, Goodrich JK, Jackson MA, Yet I, Davenport ER, VieiraSilva S, Debelius J, Pallister T, Mangino M, Raes J, Knight R, Clark AG, Ley RE, Spector TD, Bell JT (2016) Heritable components of the human fecal microbiome are associated with visceral fat. Genome Biol 17:189

Benson AK, Kelly SA, Legge R, Ma F, Low SJ, Kim J, Zhang M, Oh PL, Nehrenberg D, Hua K, Kachman SD, Moriyama EN, Walter J, Peterson DA, Pomp D (2010) Individuality in gut microbiota composition is a complex polygenic trait shaped by multiple environmental and host genetic factors. Proc Natl Acad Sci U S A 107:18933-18938

Blekhman R, Goodrich JK, Huang K, Sun Q, Bukowski R, Bell JT, Spector TD, Keinan A, Ley RE, Gevers D, Clark AG (2015) Host genetic variation impacts microbiome composition across human body sites. Genome Biol 16:191

Bonder MJ, Kurilshikov A, Tigchelaar EF, Mujagic Z, Imhann F, Vila AV, Deelen P, Vatanen T, Schirmer M, Smeekens SP, Zhernakova DV, Jankipersadsing SA, Jaeger M, Oosting M, Cenit MC, Masclee AA, Swertz MA, Li Y, Kumar V, Joosten L, Harmsen H, Weersma RK, Franke L, Hofker MH, Xavier RJ, Jonkers D, Netea MG, Wijmenga C, Fu J, Zhernakova A (2016) The effect of host genetics on the gut microbiome. Nat Genet 48:1407-1412

Brandt LJ (2012) Fecal transplantation for the treatment of clostridium difficile infection. Gastroenterol Hepatol 8:191-194

Brodziak F, Meharg C, Blaut M, Loh G (2013) Differences in mucosal gene expression in the colon of two inbred mouse strains after colonization with commensal gut bacteria. PLoS ONE 8:e72317

Bubier JA, Philip VM, Quince C, Campbell J, Zhou Y, Vishnivetskaya T, Duvvuru S, Blair RH, Ndukum J, Donohue KD, Foster CM, Mellert DJ, Weinstock G, Culiat CT, O’Hara BF, Palumbo AV,
Podar M, Chesler EJ (2020) A microbe associated with sleep revealed by a novel systems genetic analysis of the microbiome in collaborative cross mice. Genetics 214:719-733

Campbell JH, Foster CM, Vishnivetskaya T, Campbell AG, Yang ZK, Wymore A, Palumbo AV, Chesler EJ, Podar M (2012) Host genetic and environmental effects on mouse intestinal microbiota. ISME J 6:2033-2044

Caricilli AM, Picardi PK, de Abreu LL, Ueno M, Prada PO, Ropelle ER, Hirabara SM, Castoldi A, Vieira P, Camara NO, Curi R, Carvalheira JB, Saad MJ (2011) Gut microbiota is a key modulator of insulin resistance in TLR 2 knockout mice. PLoS Biol 9:e1001212

Chassaing B, Ley RE, Gewirtz AT (2014) Intestinal epithelial cell toll-like receptor 5 regulates the intestinal microbiota to prevent low-grade inflammation and metabolic syndrome in mice. Gastroenterology 147:1363-1377

Clarke G, Grenham S, Scully P, Fitzgerald P, Moloney RD, Shanahan F, Dinan TG, Cryan JF (2013) The microbiome-gut-brain axis during early life regulates the hippocampal serotonergic system in a sex-dependent manner. Mol Psychiatry 18:666-673

Coulombe G, Langlois A, De Palma G, Langlois MJ, McCarville JL, Gagne-Sanfacon J, Perreault N, Feng GS, Bercik P, Boudreau F, Verdu EF, Rivard N (2016) SHP-2 Phosphatase prevents colonic inflammation by controlling secretory cell differentiation and maintaining host-microbiota homeostasis. J Cell Physiol 231:2529-2540

Couturier-Maillard A, Secher T, Rehman A, Normand S, De Arcangelis A, Haesler R, Huot L, Grandjean T, Bressenot A, DelanoyeCrespin A, Gaillot O, Schreiber S, Lemoine Y, Ryffel B, Hot D, Nunez G, Chen G, Rosenstiel P, Chamaillard M (2013) NOD2mediated dysbiosis predisposes mice to transmissible colitis and colorectal cancer. J Clin Invest 123:700-711

Cresci GA, Thangaraju M, Mellinger JD, Liu K, Ganapathy V (2010) Colonic gene expression in conventional and germ-free mice with a focus on the butyrate receptor GPR109A and the butyrate transporter SLC5A8. J Gastrointest Surg 14:449-461

Cryan JF, O'Riordan KJ, Cowan CSM, Sandhu KV, Bastiaanssen TFS, Boehme M, Codagnone MG, Cussotto S, Fulling C, Golubeva AV, Guzzetta KE, Jaggar M, Long-Smith CM, Lyte JM, Martin JA, Molinero-Perez A, Moloney G, Morelli E, Morillas E, O'Connor R, Cruz-Pereira JS, Peterson VL, Rea K, Ritz NL, Sherwin E, Spichak S, Teichman EM, van de Wouw M, Ventura-Silva AP, Wallace-Fitzsimons SE, Hyland N, Clarke G, Dinan TG (2019) The microbiota-gut-brain axis. Physiol Rev 99:1877-2013

Davenport ER, Cusanovich DA, Michelini K, Barreiro LB, Ober C, Gilad Y (2015) Genome-wide association studies of the human gut microbiota. PLoS ONE 10:e0140301

Davie JR (2003) Inhibition of histone deacetylase activity by butyrate. J Nutr 133:2485S-2493S

Desbonnet L, Clarke G, Shanahan F, Dinan TG, Cryan JF (2014) Microbiota is essential for social development in the mouse. Mol Psychiatry 19:146-148

Di Ciaula A, Stella A, Bonfrate L, Wang DQH, Portincasa P (2020) Gut microbiota between environment and genetic background in familial mediterranean fever (FMF). Genes 11(9):1041

Diaz Heijtz R, Wang S, Anuar F, Qian Y, Bjorkholm B, Samuelsson A, Hibberd ML, Forssberg H, Pettersson S (2011) Normal gut microbiota modulates brain development and behavior. Proc Natl Acad Sci 108:3047-3052

Dominguez-Bello MG, Costello EK, Contreras M, Magris M, Hidalgo G, Fierer N, Knight R (2010) Delivery mode shapes the acquisition and structure of the initial microbiota across multiple body habitats in newborns. Proc Natl Acad Sci 107:11971-11975

Dong TS, Gupta A (2019) Influence of early life, diet, and the environment on the microbiome. Clin Gastroenterol Hepatol 17:231-242 
Dudbridge F, Gusnanto A (2008) Estimation of significance thresholds for genomewide association scans. Genet Epidemiol 32:227-234

Elinav E, Strowig T, Kau AL, Henao-Mejia J, Thaiss CA, Booth CJ, Peaper DR, Bertin J, Eisenbarth SC, Gordon JI, Flavell RA (2011) NLRP6 inflammasome regulates colonic microbial ecology and risk for colitis. Cell 145:745-757

Engen PA, Zaferiou A, Rasmussen H, Naqib A, Green SJ, Fogg LF, Forsyth CB, Raeisi S, Hamaker B, Keshavarzian A (2020) Single-arm, non-randomized, time series, single-subject study of fecal microbiota transplantation in multiple sclerosis. Front Neurol 11:978

Frank DN, Robertson CE, Hamm CM, Kpadeh Z, Zhang T, Chen H, Zhu W, Sartor RB, Boedeker EC, Harpaz N, Pace NR, Li E (2011) Disease phenotype and genotype are associated with shifts in intestinal-associated microbiota in inflammatory bowel diseases. Inflamm Bowel Dis 17:179-184

Frohlich EE, Farzi A, Mayerhofer R, Reichmann F, Jacan A, Wagner B, Zinser E, Bordag N, Magnes C, Frohlich E, Kashofer K, Gorkiewicz G, Holzer P (2016) Cognitive impairment by antibioticinduced gut dysbiosis: analysis of gut microbiota-brain communication. Brain Behav Immun 56:140-155

Furusawa Y, Obata Y, Fukuda S, Endo TA, Nakato G, Takahashi D, Nakanishi Y, Uetake C, Kato K, Kato T, Takahashi M, Fukuda NN, Murakami S, Miyauchi E, Hino S, Atarashi K, Onawa S, Fujimura Y, Lockett T, Clarke JM, Topping DL, Tomita M, Hori S, Ohara O, Morita T, Koseki H, Kikuchi J, Honda K, Hase K, Ohno H (2013) Commensal microbe-derived butyrate induces the differentiation of colonic regulatory T cells. Nature 504:446-450

Georgopoulos K, Bigby M, Wang JH, Molnar A, Wu P, Winandy S, Sharpe A (1994) The Ikaros gene is required for the development of all lymphoid lineages. Cell 79:143-156

Geurts L, Lazarevic V, Derrien M, Everard A, Van Roye M, Knauf C, Valet P, Girard M, Muccioli GG, Francois P, de Vos WM, Schrenzel J, Delzenne NM, Cani PD (2011) Altered gut microbiota and endocannabinoid system tone in obese and diabetic leptin-resistant mice: impact on apelin regulation in adipose tissue. Front Microbiol 2:149

Gill SR, Pop M, Deboy RT, Eckburg PB, Turnbaugh PJ, Samuel BS, Gordon JI, Relman DA, Fraser-Liggett CM, Nelson KE (2006) Metagenomic analysis of the human distal gut microbiome. Science 312:1355-1359

Gomez A, Luckey D, Yeoman CJ, Marietta EV, Berg Miller ME, Murray JA, White BA, Taneja V (2012) Loss of sex and age driven differences in the gut microbiome characterize arthritissusceptible 0401 mice but not arthritis-resistant 0402 mice. PLoS ONE 7:e36095

Goodrich JK, Davenport ER, Beaumont M, Jackson MA, Knight R, Ober C, Spector TD, Bell JT, Clark AG, Ley RE (2016) Genetic determinants of the gut microbiome in UK twins. Cell Host Microbe 19:731-743

Goodrich JK, Waters JL, Poole AC, Sutter JL, Koren O, Blekhman R, Beaumont M, Van Treuren W, Knight R, Bell JT, Spector TD, Clark AG, Ley RE (2014) Human genetics shape the gut microbiome. Cell 159:789-799

Gorkiewicz G, Moschen A (2018) Gut microbiome: a new player in gastrointestinal disease. Virchows Arch 472:159-172

Goto Y, Obata T, Kunisawa J, Sato S, Ivanov II, Lamichhane A, Takeyama N, Kamioka M, Sakamoto M, Matsuki T, Setoyama H, Imaoka A, Uematsu S, Akira S, Domino SE, Kulig P, Becher B, Renauld JC, Sasakawa C, Umesaki Y, Benno Y, Kiyono H (2014) Innate lymphoid cells regulate intestinal epithelial cell glycosylation. Science 345:1254009

Grice EA, Segre JA (2012) The human microbiome: our second genome. Annu Rev Genom Hum Genet 13:151-170
Hedrich HJ (2012) The laboratory mouse, 2nd edn. Elsevier, Amsterdam

Hildebrandt MA, Hoffmann C, Sherrill-Mix SA, Keilbaugh SA, Hamady M, Chen YY, Knight R, Ahima RS, Bushman F, Wu GD (2009) High-fat diet determines the composition of the murine gut microbiome independently of obesity. Gastroenterology 137(1716-1724):e1711-1712

Hillhouse AE, Myles MH, Taylor JF, Bryda EC, Franklin CL (2011) Quantitative trait loci in a bacterially induced model of inflammatory bowel disease. Mamm Genome 22:544-555

Hooper LV, Gordon JI (2001) Commensal host-bacterial relationships in the gut. Science 292:1115-1118

Houben T, Penders J, Oligschlaeger Y, Dos Reis IAM, Bonder MJ, Koonen DP, Fu J, Hofker MH, Shiri-Sverdlov R (2019) Hematopoietic Npc1 mutation shifts gut microbiota composition in Ldlr(-/-) mice on a high-fat, high-cholesterol diet. Sci Rep 9:14956

Hughes DA, Bacigalupe R, Wang J, Ruhlemann MC, Tito RY, Falony G, Joossens M, Vieira-Silva S, Henckaerts L, Rymenans L, Verspecht C, Ring S, Franke A, Wade KH, Timpson NJ, Raes J (2020) Genome-wide associations of human gut microbiome variation and implications for causal inference analyses. Nat Microbiol 5:1079-1087

Human Microbiome Project C (2012) Structure, function and diversity of the healthy human microbiome. Nature 486:207-214

Huse SM, Ye Y, Zhou Y, Fodor AA (2012) A core human microbiome as viewed through 16S rRNA sequence clusters. PLoS ONE 7:e34242

International Human Genome Sequencing C (2004) Finishing the euchromatic sequence of the human genome. Nature 431:931-945

Ishida S, Kato K, Tanaka M, Odamaki T, Kubo R, Mitsuyama E, Xiao JZ, Yamaguchi R, Uematsu S, Imoto S, Miyano S (2020) Genome-wide association studies and heritability analysis reveal the involvement of host genetics in the Japanese gut microbiota. Commun Biol 3:686

Ivanov II, Atarashi K, Manel N, Brodie EL, Shima T, Karaoz U, Wei D, Goldfarb KC, Santee CA, Lynch SV, Tanoue T, Imaoka A, Itoh K, Takeda K, Umesaki Y, Honda K, Littman DR (2009) Induction of intestinal Th17 cells by segmented filamentous bacteria. Cell 139:485-498

Jin D, Wu S, Zhang YG, Lu R, Xia Y, Dong H, Sun J (2015) Lack of vitamin $\mathrm{D}$ receptor causes dysbiosis and changes the functions of the murine intestinal microbiome. Clin Ther 37:996-1009

Kadosh E, Snir-Alkalay I, Venkatachalam A, May S, Lasry A, Elyada E, Zinger A, Shaham M, Vaalani G, Mernberger M, Stiewe T, Pikarsky E, Oren M, Ben-Neriah Y (2020) The gut microbiome switches mutant p53 from tumour-suppressive to oncogenic. Nature 586:133-138

Kemis JH, Linke V, Barrett KL, Boehm FJ, Traeger LL, Keller MP, Rabaglia ME, Schueler KL, Stapleton DS, Gatti DM, Churchill GA, Amador-Noguez D, Russell JD, Yandell BS, Broman KW, Coon JJ, Attie AD, Rey FE (2019) Genetic determinants of gut microbiota composition and bile acid profiles in mice. PLoS Genet 15:e1008073

Khachatryan ZA, Ktsoyan ZA, Manukyan GP, Kelly D, Ghazaryan KA, Aminov RI (2008) Predominant role of host genetics in controlling the composition of gut microbiota. PLoS ONE 3:e3064

Knights D, Silverberg MS, Weersma RK, Gevers D, Dijkstra G, Huang $\mathrm{H}$, Tyler AD, van Sommeren S, Imhann F, Stempak JM, Huang H, Vangay P, Al-Ghalith GA, Russell C, Sauk J, Knight J, Daly MJ, Huttenhower C, Xavier RJ (2014) Complex host genetics influence the microbiome in inflammatory bowel disease. Genome Med 6:107

Krautkramer KA, Dhillon RS, Denu JM, Carey HV (2017) Metabolic programming of the epigenome: host and gut 
microbial metabolite interactions with host chromatin. Transl Res 189:30-50

Krautkramer KA, Fan J, Backhed F (2021) Gut microbial metabolites as multi-kingdom intermediates. Nat Rev Microbiol 19:77-94

Krych L, Hansen CH, Hansen AK, van den Berg FW, Nielsen DS (2013) Quantitatively different, yet qualitatively alike: a metaanalysis of the mouse core gut microbiome with a view towards the human gut microbiome. PLoS ONE 8:e62578

Kurilshikov A, Medina-Gomez C, Bacigalupe R, Radjabzadeh D, Wang J, Demirkan A, Le Roy CI, Raygoza Garay JA, Finnicum CT, Liu X, Zhernakova DV, Bonder MJ, Hansen TH, Frost F, Ruhlemann MC, Turpin W, Moon JY, Kim HN, Lull K, Barkan E, Shah SA, Fornage M, Szopinska-Tokov J, Wallen ZD, Borisevich D, Agreus L, Andreasson A, Bang C, Bedrani L, Bell JT, Bisgaard H, Boehnke M, Boomsma DI, Burk RD, Claringbould A, Croitoru K, Davies GE, van Duijn CM, Duijts L, Falony G, Fu J, van der Graaf A, Hansen T, Homuth G, Hughes DA, Ijzerman RG, Jackson MA, Jaddoe VWV, Joossens M, Jorgensen T, Keszthelyi D, Knight R, Laakso M, Laudes M, Launer LJ, Lieb W, Lusis AJ, Masclee AAM, Moll HA, Mujagic Z, Qibin Q, Rothschild D, Shin H, Sorensen SJ, Steves CJ, Thorsen J, Timpson NJ, Tito RY, Vieira-Silva S, Volker U, Volzke H, Vosa U, Wade $\mathrm{KH}$, Walter S, Watanabe K, Weiss S, Weiss FU, Weissbrod O, Westra HJ, Willemsen G, Payami H, Jonkers D, Arias Vasquez A, de Geus EJC, Meyer KA, Stokholm J, Segal E, Org E, Wijmenga C, Kim HL, Kaplan RC, Spector TD, Uitterlinden AG, Rivadeneira F, Franke A, Lerch MM, Franke L, Sanna S, D'Amato M, Pedersen O, Paterson AD, Kraaij R, Raes J, Zhernakova A (2021) Large-scale association analyses identify host factors influencing human gut microbiome composition. Nat Genet 53:156-165

Lagkouvardos I, Pukall R, Abt B, Foesel BU, Meier-Kolthoff JP, Kumar N, Bresciani A, Martinez I, Just S, Ziegler C, Brugiroux S, Garzetti D, Wenning M, Bui TP, Wang J, Hugenholtz F, Plugge CM, Peterson DA, Hornef MW, Baines JF, Smidt H, Walter J, Kristiansen K, Nielsen HB, Haller D, Overmann J, Stecher B, Clavel $\mathrm{T}$ (2016) The mouse intestinal bacterial collection ( $\mathrm{miBC}$ ) provides host-specific insight into cultured diversity and functional potential of the gut microbiota. Nat Microbiol 1:16131

Lamas B, Richard ML, Leducq V, Pham HP, Michel ML, Da Costa G, Bridonneau C, Jegou S, Hoffmann TW, Natividad JM, Brot L, Taleb S, Couturier-Maillard A, Nion-Larmurier I, Merabtene F, Seksik P, Bourrier A, Cosnes J, Ryffel B, Beaugerie L, Launay JM, Langella P, Xavier RJ, Sokol H (2016) CARD9 impacts colitis by altering gut microbiota metabolism of tryptophan into aryl hydrocarbon receptor ligands. Nat Med 22:598-605

Laposky AD, Bradley MA, Williams DL, Bass J, Turek FW (2008) Sleep-wake regulation is altered in leptin-resistant $(\mathrm{db} / \mathrm{db})$ genetically obese and diabetic mice. Am J Physiol Regul Integr Comp Physiol 295:R2059-2066

Le Roy CI, Beaumont M, Jackson MA, Steves CJ, Spector TD, Bell JT (2018) Heritable components of the human fecal microbiome are associated with visceral fat. Gut Microbes 9:61-67

Leamy LJ, Kelly SA, Nietfeldt J, Legge RM, Ma F, Hua K, Sinha R, Peterson DA, Walter J, Benson AK, Pomp D (2014) Host genetics and diet, but not immunoglobulin A expression, converge to shape compositional features of the gut microbiome in an advanced intercross population of mice. Genome Biol 15:552

Lee-Sarwar KA, Lasky-Su J, Kelly RS, Litonjua AA, Weiss ST (2020) Metabolome-microbiome crosstalk and human disease. Metabolites 10(5): 181

Ley RE, Backhed F, Turnbaugh P, Lozupone CA, Knight RD, Gordon JI (2005) Obesity alters gut microbial ecology. Proc Natl Acad Sci 102:11070-11075

Li Y, Chen QQ, Yuan J, Chen Z, Du HT, Wan J (2020) Altered microbial community structure in PI3Kgamma knockout mice with colitis impeding relief of inflammation: establishment of new indices for intestinal microbial disorder. Int Immunopharmacol 79:105901

Lim MY, You HJ, Yoon HS, Kwon B, Lee JY, Lee S, Song YM, Lee K, Sung J, Ko G (2017) The effect of heritability and host genetics on the gut microbiota and metabolic syndrome. Gut 66:1031-1038

Liu WH, Chuang HL, Huang YT, Wu CC, Chou GT, Wang S, Tsai YC (2016) Alteration of behavior and monoamine levels attributable to Lactobacillus plantarum PS128 in germ-free mice. Behav Brain Res 298:202-209

Liu W, Yan M, Liu Y, Wang R, Li C, Deng C, Singh A, Coleman WG Jr, Rodgers GP (2010) Olfactomedin 4 down-regulates innate immunity against Helicobacter pylori infection. Proc Natl Acad Sci 107:11056-11061

Liu C, Zhou N, Du MX, Sun YT, Wang K, Wang YJ, Li DH, Yu HY, Song Y, Bai BB, Xin Y, Wu L, Jiang CY, Feng J, Xiang H, Zhou Y, Ma J, Wang J, Liu HW, Liu SJ (2020) The mouse gut microbial biobank expands the coverage of cultured bacteria. Nat Commun 11:79

Lundin A, Bok CM, Aronsson L, Bjorkholm B, Gustafsson JA, Pott S, Arulampalam V, Hibberd M, Rafter J, Pettersson S (2008) Gut flora, toll-like receptors and nuclear receptors: a tripartite communication that tunes innate immunity in large intestine. Cell Microbiol 10:1093-1103

Manolio TA, Collins FS, Cox NJ, Goldstein DB, Hindorff LA, Hunter DJ, McCarthy MI, Ramos EM, Cardon LR, Chakravarti A, Cho JH, Guttmacher AE, Kong A, Kruglyak L, Mardis E, Rotimi CN, Slatkin M, Valle D, Whittemore AS, Boehnke M, Clark AG, Eichler EE, Gibson G, Haines JL, Mackay TF, McCarroll SA, Visscher PM (2009) Finding the missing heritability of complex diseases. Nature 461:747-753

Matsuo K, Nagakubo D, Yamamoto S, Shigeta A, Tomida S, Fujita M, Hirata T, Tsunoda I, Nakayama T, Yoshie O (2018) CCL28deficient mice have reduced $\operatorname{IgA}$ antibody-secreting cells and an altered microbiota in the colon. J Immunol 200:800-809

McKnite AM, Perez-Munoz ME, Lu L, Williams EG, Brewer S, Andreux PA, Bastiaansen JW, Wang X, Kachman SD, Auwerx J, Williams RW, Benson AK, Peterson DA, Ciobanu DC (2012) Murine gut microbiota is defined by host genetics and modulates variation of metabolic traits. PLoS ONE 7:e39191

Mouse Genome Sequencing C, Waterston RH, Lindblad-Toh K, Birney E, Rogers J, Abril JF, Agarwal P, Agarwala R, Ainscough R, Alexandersson M, An P, Antonarakis SE, Attwood J, Baertsch R, Bailey J, Barlow K, Beck S, Berry E, Birren B, Bloom T, Bork P, Botcherby M, Bray N, Brent MR, Brown DG, Brown SD, Bult C, Burton J, Butler J, Campbell RD, Carninci P, Cawley S, Chiaromonte F, Chinwalla AT, Church DM, Clamp M, Clee C, Collins FS, Cook LL, Copley RR, Coulson A, Couronne O, Cuff J, Curwen V, Cutts T, Daly M, David R, Davies J, Delehaunty KD, Deri J, Dermitzakis ET, Dewey C, Dickens NJ, Diekhans M, Dodge S, Dubchak I, Dunn DM, Eddy SR, Elnitski L, Emes RD, Eswara P, Eyras E, Felsenfeld A, Fewell GA, Flicek P, Foley K, Frankel WN, Fulton LA, Fulton RS, Furey TS, Gage D, Gibbs RA, Glusman G, Gnerre S, Goldman N, Goodstadt L, Grafham D, Graves TA, Green ED, Gregory S, Guigo R, Guyer M, Hardison RC, Haussler D, Hayashizaki Y, Hillier LW, Hinrichs A, Hlavina W, Holzer T, Hsu F, Hua A, Hubbard T, Hunt A, Jackson I, Jaffe DB, Johnson LS, Jones M, Jones TA, Joy A, Kamal M, Karlsson EK, Karolchik D, Kasprzyk A, Kawai J, Keibler E, Kells C, Kent WJ, Kirby A, Kolbe DL, Korf I, Kucherlapati RS, Kulbokas EJ, Kulp D, Landers T, Leger JP, Leonard S, Letunic I, Levine R, Li J, Li M, Lloyd C, Lucas S, Ma B, Maglott DR, Mardis ER, Matthews L, Mauceli E, Mayer JH, McCarthy M, McCombie WR, McLaren S, McLay K, McPherson JD, Meldrim J, Meredith B, Mesirov JP, Miller W, Miner TL, Mongin 
E, Montgomery KT, Morgan M, Mott R, Mullikin JC, Muzny DM, Nash WE, Nelson JO, Nhan MN, Nicol R, Ning Z, Nusbaum C, O'Connor MJ, Okazaki Y, Oliver K, Overton-Larty E, Pachter L, Parra G, Pepin KH, Peterson J, Pevzner P, Plumb R, Pohl CS, Poliakov A, Ponce TC, Ponting CP, Potter S, Quail M, Reymond A, Roe BA, Roskin KM, Rubin EM, Rust AG, Santos R, Sapojnikov V, Schultz B, Schultz J, Schwartz MS, Schwartz S, Scott C, Seaman S, Searle S, Sharpe T, Sheridan A, Shownkeen R, Sims S, Singer JB, Slater G, Smit A, Smith DR, Spencer B, Stabenau A, Stange-Thomann N, Sugnet C, Suyama M, Tesler G, Thompson J, Torrents D, Trevaskis E, Tromp J, Ucla C, Ureta-Vidal A, Vinson JP, Von Niederhausern AC, Wade CM, Wall M, Weber RJ, Weiss RB, Wendl MC, West AP, Wetterstrand K, Wheeler R, Whelan S, Wierzbowski J, Willey D, Williams S, Wilson RK, Winter E, Worley KC, Wyman D, Yang S, Yang SP, Zdobnov EM, Zody MC, Lander ES (2002) Initial sequencing and comparative analysis of the mouse genome. Nature 420:520-562

Neufeld KM, Kang N, Bienenstock J, Foster JA (2011) Reduced anxiety-like behavior and central neurochemical change in germ-free mice. Neurogastroenterol Motil 23:255-264

Niska-Blakie J, Gopinathan L, Low KN, Kien YL, Goh CMF, Caldez MJ, Pfeiffenberger E, Jones OS, Ong CB, Kurochkin IV, Coppola V, Tessarollo L, Choi H, Kanagasundaram Y, Eisenhaber F, Maurer-Stroh S, Kaldis P (2020) Knockout of the non-essential gene SUGCT creates diet-linked, age-related microbiome disbalance with a diabetes-like metabolic syndrome phenotype. Cell Mol Life Sci 77:3423-3439

Org E, Parks BW, Joo JW, Emert B, Schwartzman W, Kang EY, Mehrabian M, Pan C, Knight R, Gunsalus R, Drake TA, Eskin E, Lusis AJ (2015) Genetic and environmental control of host-gut microbiota interactions. Genome Res 25:1558-1569

Oz-Levi D, Olender T, Bar-Joseph I, Zhu Y, Marek-Yagel D, Barozzi I, Osterwalder M, Alkelai A, Ruzzo EK, Han Y, Vos ESM, Reznik-Wolf H, Hartman C, Shamir R, Weiss B, Shapiro R, Pode-Shakked B, Tatarskyy P, Milgrom R, Schvimer M, Barshack I, Imai DM, Coleman-Derr D, Dickel DE, Nord AS, Afzal V, van Bueren KL, Barnes RM, Black BL, Mayhew CN, Kuhar MF, Pitstick A, Tekman M, Stanescu HC, Wells JM, Kleta R, de Laat W, Goldstein DB, Pras E, Visel A, Lancet D, Anikster Y, Pennacchio LA (2019) Noncoding deletions reveal a gene that is critical for intestinal function. Nature 571:107-111

Perez-Munoz ME, McKnite AM, Williams EG, Auwerx J, Williams RW, Peterson DA, Ciobanu DC (2019) Diet modulates cecum bacterial diversity and physiological phenotypes across the BXD mouse genetic reference population. PLoS ONE 14:e0224100

Perry MN, Bello SM, Smith CL (2020) Know your model: microbiota \& phenotypes. Lab Anim 49:301-302

Pierantonelli I, Rychlicki C, Agostinelli L, Giordano DM, Gaggini M, Fraumene C, Saponaro C, Manghina V, Sartini L, Mingarelli E, Pinto C, Buzzigoli E, Trozzi L, Giordano A, Marzioni M, Minicis S, Uzzau S, Cinti S, Gastaldelli A, Svegliati-Baroni G (2017) Lack of NLRP3-inflammasome leads to gut-liver axis derangement, gut dysbiosis and a worsened phenotype in a mouse model of NAFLD. Sci Rep 7:12200

Pozzilli P, Signore A, Williams AJ, Beales PE (1993) NOD mouse colonies around the world-recent facts and figures. Immunol Today 14:193-196

Rallabhandi P, Awomoyi A, Thomas KE, Phalipon A, Fujimoto Y, Fukase K, Kusumoto S, Qureshi N, Sztein MB, Vogel SN (2008) Differential activation of human TLR4 by Escherichia coli and Shigella flexneri 2a lipopolysaccharide: combined effects of lipid A acylation state and TLR4 polymorphisms on signaling. J Immunol 180:1139-1147

Rausch P, Rehman A, Kunzel S, Hasler R, Ott SJ, Schreiber S, Rosenstiel P, Franke A, Baines JF (2011) Colonic mucosa-associated microbiota is influenced by an interaction of Crohn disease and FUT2 (Secretor) genotype. Proc Natl Acad Sci 108:19030-19035

Rehman A, Sina C, Gavrilova O, Hasler R, Ott S, Baines JF, Schreiber S, Rosenstiel P (2011) Nod2 is essential for temporal development of intestinal microbial communities. Gut 60:1354-1362

Ridaura VK, Faith JJ, Rey FE, Cheng J, Duncan AE, Kau AL, Griffin NW, Lombard V, Henrissat B, Bain JR, Muehlbauer MJ, Ilkayeva O, Semenkovich CF, Funai K, Hayashi DK, Lyle BJ, Martini MC, Ursell LK, Clemente JC, Van Treuren W, Walters WA, Knight R, Newgard CB, Heath AC, Gordon JI (2013) Gut microbiota from twins discordant for obesity modulate metabolism in mice. Science 341:1241214

Rothschild D, Weissbrod O, Barkan E, Kurilshikov A, Korem T, Zeevi D, Costea PI, Godneva A, Kalka IN, Bar N, Shilo S, Lador D, Vila AV, Zmora N, Pevsner-Fischer M, Israeli D, Kosower N, Malka G, Wolf BC, Avnit-Sagi T, Lotan-Pompan M, Weinberger A, Halpern Z, Carmi S, Fu J, Wijmenga C, Zhernakova A, Elinav E, Segal E (2018) Environment dominates over host genetics in shaping human gut microbiota. Nature 555:210-215

Saha S, Jing X, Park SY, Wang S, Li X, Gupta D, Dziarski R (2010) Peptidoglycan recognition proteins protect mice from experimental colitis by promoting normal gut flora and preventing induction of interferon-gamma. Cell Host Microbe 8:147-162

Salzman NH, Hung K, Haribhai D, Chu H, Karlsson-Sjoberg J, Amir E, Teggatz P, Barman M, Hayward M, Eastwood D, Stoel M, Zhou Y, Sodergren E, Weinstock GM, Bevins CL, Williams CB, Bos NA (2010) Enteric defensins are essential regulators of intestinal microbial ecology. Nat Immunol 11:76-83

Sampson TR, Debelius JW, Thron T, Janssen S, Shastri GG, Ilhan ZE, Challis C, Schretter CE, Rocha S, Gradinaru V, Chesselet MF, Keshavarzian A, Shannon KM, Krajmalnik-Brown R, Wittung-Stafshede P, Knight R, Mazmanian SK (2016) Gut microbiota regulate motor deficits and neuroinflammation in a model of Parkinson's disease. Cell 167:1469-1480

Saul MC, Philip VM, Reinholdt LG, Chesler EJ, Center for Systems Neurogenetics of A (2019) High-diversity mouse populations for complex traits. Trends Genet 35:501-514

Schepici G, Silvestro S, Bramanti P, Mazzon E (2019) The gut microbiota in multiple sclerosis: an overview of clinical trials. Cell Transplant 28:1507-1527

Scher JU, Sczesnak A, Longman RS, Segata N, Ubeda C, Bielski C, Rostron T, Cerundolo V, Pamer EG, Abramson SB, Huttenhower C, Littman DR (2013) Expansion of intestinal Prevotella copri correlates with enhanced susceptibility to arthritis. Elife 2: $\mathrm{e} 01202$

Sender R, Fuchs S, Milo R (2016) Are we really vastly outnumbered? Revisiting the ratio of bacterial to host cells in humans. Cell 164:337-340

Shreiner AB, Kao JY, Young VB (2015) The gut microbiome in health and in disease. Curr Opin Gastroenterol 31:69-75

Snijders AM, Langley SA, Kim YM, Brislawn CJ, Noecker C, Zink EM, Fansler SJ, Casey CP, Miller DR, Huang Y, Karpen GH, Celniker SE, Brown JB, Borenstein E, Jansson JK, Metz TO, Mao JH (2016) Influence of early life exposure, host genetics and diet on the mouse gut microbiome and metabolome. Nat Microbiol 2:16221

Suez J, Korem T, Zeevi D, Zilberman-Schapira G, Thaiss CA, Maza O, Israeli D, Zmora N, Gilad S, Weinberger A, Kuperman Y, Harmelin A, Kolodkin-Gal I, Shapiro H, Halpern Z, Segal E, Elinav E (2014) Artificial sweeteners induce glucose intolerance by altering the gut microbiota. Nature 514:181-186

Suzuki K, Meek B, Doi Y, Muramatsu M, Chiba T, Honjo T, Fagarasan S (2004) Aberrant expansion of segmented filamentous bacteria in IgA-deficient gut. Proc Natl Acad Sci 101:1981-1986 
Suzuki TA, Phifer-Rixey M, Mack KL, Sheehan MJ, Lin D, Bi K, Nachman MW (2019) Host genetic determinants of the gut microbiota of wild mice. Mol Ecol 28:3197-3207

Svenson KL, Gatti DM, Valdar W, Welsh CE, Cheng R, Chesler EJ, Palmer AA, McMillan L, Churchill GA (2012) High-resolution genetic mapping using the mouse diversity outbred population. Genetics 190:437-447

Tam V, Patel N, Turcotte M, Bosse Y, Pare G, Meyre D (2019) Benefits and limitations of genome-wide association studies. Nat Rev Genet 20:467-484

Truax AD, Chen L, Tam JW, Cheng N, Guo H, Koblansky AA, Chou WC, Wilson JE, Brickey WJ, Petrucelli A, Liu R, Cooper DE, Koenigsknecht MJ, Young VB, Netea MG, Stienstra R, Sartor RB, Montgomery SA, Coleman RA, Ting JP (2018) The inhibitory innate immune sensor nlrp12 maintains a threshold against obesity by regulating gut microbiota homeostasis. Cell Host Microbe 24:364-378

Turnbaugh PJ, Backhed F, Fulton L, Gordon JI (2008) Diet-induced obesity is linked to marked but reversible alterations in the mouse distal gut microbiome. Cell Host Microbe 3:213-223

Turnbaugh PJ, Hamady M, Yatsunenko T, Cantarel BL, Duncan A, Ley RE, Sogin ML, Jones WJ, Roe BA, Affourtit JP, Egholm M, Henrissat B, Heath AC, Knight R, Gordon JI (2009) A core gut microbiome in obese and lean twins. Nature 457:480-484

Turpin W, Espin-Garcia O, Xu W, Silverberg MS, Kevans D, Smith MI, Guttman DS, Griffiths A, Panaccione R, Otley A, Xu L, Shestopaloff K, Moreno-Hagelsieb G, Paterson AD, Croitoru K (2016) Association of host genome with intestinal microbial composition in a large healthy cohort. Nat Genet 48:1413-1417

Vaishnava S, Yamamoto M, Severson KM, Ruhn KA, Yu X, Koren O, Ley R, Wakeland EK, Hooper LV (2011) The antibacterial lectin RegIIIgamma promotes the spatial segregation of microbiota and host in the intestine. Science 334:255-258

van Opstal EJ, Bordenstein SR (2015) Rethinking heritability of the microbiome. Science 349:1172-1173

Vijay-Kumar M, Aitken JD, Carvalho FA, Cullender TC, Mwangi S, Srinivasan S, Sitaraman SV, Knight R, Ley RE, Gewirtz AT (2010) Metabolic syndrome and altered gut microbiota in mice lacking toll-like receptor 5. Science 328:228-231

Wacklin P, Makivuokko H, Alakulppi N, Nikkila J, Tenkanen H, Rabina J, Partanen J, Aranko K, Matto J (2011) Secretor genotype (FUT2 gene) is strongly associated with the composition of Bifidobacteria in the human intestine. PLoS ONE 6:e20113

Walter J, Armet AM, Finlay BB, Shanahan F (2020) Establishing or exaggerating causality for the gut microbiome: lessons from human microbiota-associated rodents. Cell 180:221-232

Wang J, Kalyan S, Steck N, Turner LM, Harr B, Kunzel S, Vallier M, Hasler R, Franke A, Oberg HH, Ibrahim SM, Grassl GA, Kabelitz D, Baines JF (2015) Analysis of intestinal microbiota in hybrid house mice reveals evolutionary divergence in a vertebrate hologenome. Nat Commun 6:6440

Wang J, Thingholm LB, Skieceviciene J, Rausch P, Kummen M, Hov JR, Degenhardt F, Heinsen FA, Ruhlemann MC, Szymczak S, Holm K, Esko T, Sun J, Pricop-Jeckstadt M, Al-Dury S, Bohov P, Bethune J, Sommer F, Ellinghaus D, Berge RK, Hubenthal M, Koch M, Schwarz K, Rimbach G, Hubbe P, Pan WH, Sheibani-Tezerji R, Hasler R, Rosenstiel P, D'Amato M, Cloppenborg-Schmidt K, Kunzel S, Laudes M, Marschall HU, Lieb W, Nothlings U, Karlsen TH, Baines JF, Franke A (2016) Genome-wide association analysis identifies variation in vitamin D receptor and other host factors influencing the gut microbiota. Nat Genet 48:1396-1406

Wei M, Shinkura R, Doi Y, Maruya M, Fagarasan S, Honjo T (2011) Mice carrying a knock-in mutation of aicda resulting in a defect in somatic hypermutation have impaired gut homeostasis and compromised mucosal defense. Nat Immunol 12:264-270
Wen L, Ley RE, Volchkov PY, Stranges PB, Avanesyan L, Stonebraker AC, Hu C, Wong FS, Szot GL, Bluestone JA, Gordon JI, Chervonsky AV (2008) Innate immunity and intestinal microbiota in the development of Type 1 diabetes. Nature 455:1109-1113

Wilcox MH, McGovern BH, Hecht GA (2020) The efficacy and safety of fecal microbiota transplant for recurrent clostridiumdifficile infection: current understanding and gap analysis. Open Forum Infect Dis. https://doi.org/10.1093/ofid/ofaa114

Wilkins LJ, Monga M, Miller AW (2019) Defining dysbiosis for a cluster of chronic diseases. Sci Rep 9:12918

Wilson CL, Ouellette AJ, Satchell DP, Ayabe T, Lopez-Boado YS, Stratman JL, Hultgren SJ, Matrisian LM, Parks WC (1999) Regulation of intestinal alpha-defensin activation by the metalloproteinase matrilysin in innate host defense. Science 286:113-117

Wolf KJ, Daft JG, Tanner SM, Hartmann R, Khafipour E, Lorenz RG (2014) Consumption of acidic water alters the gut microbiome and decreases the risk of diabetes in NOD mice. J Histochem Cytochem 62:237-250

Wu SE, Hashimoto-Hill S, Woo V, Eshleman EM, Whitt J, Engleman L, Karns R, Denson LA, Haslam DB, Alenghat T (2020) Microbiota-derived metabolite promotes HDAC3 activity in the gut. Nature 586:108-112

Xiao L, Feng Q, Liang S, Sonne SB, Xia Z, Qiu X, Li X, Long H, Zhang J, Zhang D, Liu C, Fang Z, Chou J, Glanville J, Hao Q, Kotowska D, Colding C, Licht TR, Wu D, Yu J, Sung JJ, Liang Q, Li J, Jia H, Lan Z, Tremaroli V, Dworzynski P, Nielsen HB, Backhed F, Dore J, Le Chatelier E, Ehrlich SD, Lin JC, Arumugam M, Wang J, Madsen L, Kristiansen K (2015) A catalog of the mouse gut metagenome. Nat Biotechnol 33:1103-1108

Xie H, Guo R, Zhong H, Feng Q, Lan Z, Qin B, Ward KJ, Jackson MA, Xia Y, Chen X, Chen B, Xia H, Xu C, Li F, Xu X, Al-Aama JY, Yang H, Wang J, Kristiansen K, Wang J, Steves CJ, Bell JT, Li J, Spector TD, Jia H (2016) Shotgun metagenomics of 250 adult twins reveals genetic and environmental impacts on the gut microbiome. Cell Syst 3:572-584

Yang L, Liu C, Zhao W, He C, Ding J, Dai R, Xu K, Xiao L, Luo L, Liu S, Li W, Meng H (2018) Impaired autophagy in intestinal epithelial cells alters gut microbiota and host immune responses. Appl Environ Microbiol. https://doi.org/10.1128/AEM.00880-18

Yang J, Fu X, Liao X, Li Y (2020) Effects of gut microbial-based treatments on gut microbiota, behavioral symptoms, and gastrointestinal symptoms in children with autism spectrum disorder: a systematic review. Psychiatry Res 293:113471

Zhang C, Zhang M, Wang S, Han R, Cao Y, Hua W, Mao Y, Zhang X, Pang X, Wei C, Zhao G, Chen Y, Zhao L (2010) Interactions between gut microbiota, host genetics and diet relevant to development of metabolic syndromes in mice. ISME J 4:232-241

Zheng P, Zeng B, Zhou C, Liu M, Fang Z, Xu X, Zeng L, Chen J, Fan S, Du X, Zhang X, Yang D, Yang Y, Meng H, Li W, Melgiri ND, Licinio J, Wei H, Xie P (2016) Gut microbiome remodeling induces depressive-like behaviors through a pathway mediated by the host's metabolism. Mol Psychiatry 21:786-796

Zhou Y, Gao H, Mihindukulasuriya KA, La Rosa PS, Wylie KM, Vishnivetskaya T, Podar M, Warner B, Tarr PI, Nelson DE, Fortenberry JD, Holland MJ, Burr SE, Shannon WD, Sodergren E, Weinstock GM (2013) Biogeography of the ecosystems of the healthy human body. Genome Biol 14:R1

Publisher's Note Springer Nature remains neutral with regard to jurisdictional claims in published maps and institutional affiliations. 